\title{
1 Temporal and spatial variation in major ion chemistry and source 2 identification of inorganic aerosols in northern Zhejiang Province, China
}

3

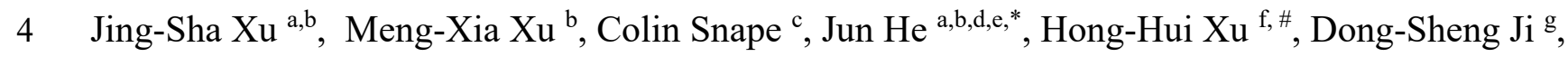
5 Cheng-Jun Wang ${ }^{\mathrm{h}}$, Huan Yu ${ }^{\mathrm{i}}$, Hang Xiao ${ }^{\mathrm{j}, \mathrm{k}}$, Yu-Jun Jiang ${ }^{\mathrm{f}}$, Bing Qi ${ }^{1}$, Rong-Guang Du ${ }^{1}$

6 a International Doctoral Innovation Centre, University of Nottingham Ningbo China, Ningbo, PR China

$7 \quad \mathrm{~b}$ Department of Chemical and Environmental Engineering, University of Nottingham Ningbo China, Ningbo, PR

8 China

$9 \quad{ }^{\mathrm{c}}$ Faculty of Engineering, University of Nottingham, University Park, Nottingham NG7 2RD, UK

$10 \mathrm{~d}$ Centre for Sustainable Energy Technologies, University of Nottingham Ningbo China, Ningbo, PR China

11 e Jiangsu Collaborative Innovation Center of Atmospheric Environment and Equipment Technology (CICAEET),

12 Nanjing University of Information Science \& Technology, Jiangsu Key Laboratory of Atmospheric Environment

13 Monitoring and Pollution Control (AEMPC), Nanjing, PR China

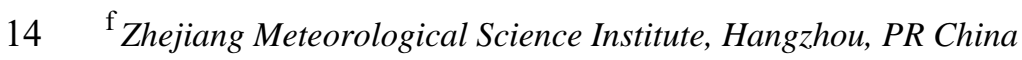

$15 \mathrm{~g}$ State Key Laboratory of Atmospheric Boundary Layer Physics and Atmospheric Chemistry, Institute of

16 Atmospheric Physics, Chinese Academy of Sciences, Beijing, PR China

$17{ }^{\mathrm{h}}$ College of Chemistry and Materials Engineering, Wenzhou University, Wenzhou, PR China

18 i School of Environmental Science and Engineering, Nanjing University of Information Science and Technology,

19 Nanjing, PR China

$20{ }^{\mathrm{j}}$ Hazardous Air Pollutants Lab, Institute of Urban Environment, Chinese Academy of Sciences, Xiamen, PR China

$21{ }^{\mathrm{k}}$ Ningbo Urban Environment Observation and Research Station-NUEORS, Chinese Academy of Sciences, Ningbo,

22 PR China

$23{ }^{1}$ Hangzhou Meteorological Bureau, Hangzhou, PR China

24

$25 *$ Corresponding author, email: jun.he@nottingham.edu.cn

$26{ }^{\#}$ Corresponding author, email: forsnow@126.com 


\section{Abstract}

28 To investigate the seasonal and spatial variations of ion chemistry on fine particles in northern

29 Zhejiang Province (NZP), China, a year-long field study was carried out at 4 representative sites

30 (2 urban, 1 suburb and 1 rural sites) in both Hangzhou and Ningbo cities from November 2014 to

31 November 2015. Twelve water soluble inorganic ions (WSII) have been characterized in this

32 study. In NZP, the annual averaged $\mathrm{PM}_{2.5}$ concentration was $66.2 \pm 37.7 \mu \mathrm{g} \mathrm{m}^{-3}$ and urban sites

33 were observed with more severe $\mathrm{PM}_{2.5}$ pollution than the suburban and rural sites; the annual

34 averaged total WSII concentration was $29.1 \pm 19.9 \mu \mathrm{g} \mathrm{m}^{-3}$, dominated by $\mathrm{SO}_{4}^{2-}\left(10.3 \mu \mathrm{g} \mathrm{m} \mathrm{m}^{-3}\right)$,

$35 \mathrm{NO}_{3}^{-}\left(8.9 \mu \mathrm{g} \mathrm{m}^{-3}\right), \mathrm{NH}_{4}^{+}\left(6.6 \mu \mathrm{g} \mathrm{m}^{-3}\right), \mathrm{Cl}^{-}\left(1.3 \mu \mathrm{g} \mathrm{m}^{-3}\right)$ and $\mathrm{K}^{+}\left(0.7 \mu \mathrm{g} \mathrm{m}^{-3}\right) . \mathrm{NH}_{4}^{+}$was highly

36 correlated with $\mathrm{NO}_{3}^{-}$and $\mathrm{SO}_{4}{ }^{2-}(\mathrm{r}: 0.8 \sim 1.0)$ throughout the sampling period at 4 sites and the

37 annual averaged molar ratio of $\left[\mathrm{NH}_{4}{ }^{+}\right] /\left[\mathrm{SO}_{4}{ }^{2-}\right]$ of 4 sites were all above 3.3 , indicating $\mathrm{NH}_{4}^{+}$

38 existed predominantly as $\left(\mathrm{NH}_{4}\right)_{2} \mathrm{SO}_{4}, \mathrm{NH}_{4} \mathrm{HSO}_{4}$ and $\mathrm{NH}_{4} \mathrm{NO}_{3}$ in aerosols, which was also the

39 predominant neutralizing cation with the highest neutralization factor (NF). The seasonal

40 patterns of SOR and NOR values were opposite to each other, which seemed influenced by

41 seasonal weather conditions and inter-relationships of $\mathrm{SO}_{2}-\mathrm{SO}_{4}{ }^{-}$and $\mathrm{NO}_{2}-\mathrm{NO}_{3}{ }^{-}$

42 transformations. Principal component analysis (PCA) showed that the predominant sources of

43 WSII in NZP were industrial emissions, biomass burning, and secondary inorganic aerosols; in

44 addition, transboundary transport of polluted aerosols also contributed based on air mass

45 backward trajectory.

\section{Keywords}

47 Northern Zhejiang Province, $\mathrm{PM}_{2.5}$, inorganic ions, temporal and spatial variability, PCA 


\section{Introduction}

Atmospheric aerosols, especially fine particles (aerodynamic diameter of $\leq 2.5 \mu \mathrm{m}, \mathrm{PM}_{2.5}$ ), comprising a complex mixture of suspended solid particles and liquid droplets, have received a

51 lot of attention over the recent decades due to their important roles in affecting ecology, climate change, visibility and public health, such as respiratory diseases, cardiopulmonary mortality and lung cancer (Pope et al., 2002; Pope and Dockery, 2006; Fang et al., 2011; He et al., 2011; Xu et al., 2016a). In terms of the sources and formation processes, they are basically classified as primary and secondary aerosols; the former are emitted directly from various sources; while the latter are formed through gas-particle transformation. For example, gaseous $\mathrm{SO}_{2}$ and $\mathrm{NO}_{2}$ emitted mostly from coal-fired power plants and vehicles can be oxidized and converted to $\mathrm{SO}_{4}{ }^{2-}$ and $\mathrm{NO}_{3}^{-}$in the atmosphere through heterogeneous and homogeneous reactions (Kang et al., 2010; Lin et al., 2009). Then these inorganic species can be converted to secondary aerosol particles such as $\left(\mathrm{NH}_{4}\right)_{2} \mathrm{SO}_{4}, \mathrm{NH}_{4} \mathrm{HSO}_{4}$, and $\mathrm{NH}_{4} \mathrm{NO}_{3}$ through the neutralization reactions with

$61 \mathrm{NH}_{4}^{+}$, which is originated from gas-phase $\mathrm{NH}_{3}$. It is reported secondary inorganic aerosols

62 (sulfate, nitrate and ammonium (SNA)) are one of the most significant contributors to particulate 63 matters (Waldman et al., 1991; He and Balasubramanian, 2008), accounting for one third or 64 more of fine particles (Meng et al., 2016; Tsai and Chen, 2006; Wang et al., 2006); and they are 65 also reported to be one of the most important factors leading to visibility impairment (Kang et atmospheric oxidants etc. (Baek et al., 2004; Deng et al., 2015; Pathak et al., 2009). 
71 components of atmospheric aerosols, water-soluble components are of great interest in urban

72 atmosphere due to their impact on controlling the aerosol acidity and environmental acidification

73 (Deng et al., 2015). The earliest studies on WSII can be traced back to 1990s in China (Waldman

74 et al., 1991), and after that a number of researches have been conducted in many cities to

75 investigate the characteristics of water-soluble inorganic ions, such as Xiamen (Zhao et al., 2011),

76 Handan (Meng et al., 2016), Guangzhou (Hu et al., 2008), Jinan (Gao et al., 2011) and Beijing

77 (Hu et al., 2014; Huang et al., 2016), etc. Yangtze River Delta (YRD) is one of the largest city-

78 clusters and economically well-developed regions in China, and WSII characteristics of severe

79 aerosol pollution in this region have also been reported to some extent. In a western city of YRD-

80 Nanjing, Wang et al. (2016b) studied the seasonal and diurnal variations and sources of water-

81 soluble inorganic ions based on one-year online measurement data. Qiao et al. (2015)

82 investigated the seasonal variation of WSII in $\mathrm{PM}_{1}$ and their effects on haze episodes in

83 Shanghai. Hua et al. (2015) studied the ion characteristics of $\mathrm{PM}_{2.5}$ during a severe haze episode

84 by a joint field observations at five cities in YRD and the source apportionment indicated that

$85 \mathrm{PM}_{2.5}$ was predominantly from secondary pollutants and primary emissions of vehicles and

86 biomass burning. In an offshore site at east coastal line of Jiangsu Province, Kong et al. (2014)

87 investigated the ion chemistry including the ion mass concentration, ion balance and sea salt

88 contributions of size-segregated aerosols in autumn 2012 and found the sea salt contribution

89 could be ignored despite its geographical closeness to the East China Sea. Most of the previous

90 studies of ionic chemistry in fine aerosols in this region have been either based on a particular

91 haze episode or a particular sampling site, which may not represent the seasonal ion pollution

92 characteristics of the YRD region well. Due to the absence of long-term observation of

93 atmospheric inorganic ions in this region, Wang et al. (2015a) investigated the seasonal 
94 variations and sources of water-soluble inorganic ions in size-fractionated aerosols of 5 urban 95 sites in YRD, but their data lacked the comparisons among the ion chemistry in urban, suburban 96 and rural areas in YRD. In this respect, the investigation of the seasonal ion chemistry and

97 sources in fine particles of urban, suburban and rural sites in YRD should be valuable to filling such a gap and gain further knowledge of how ion chemistry in fine particles of various 99 representative sites in this region might differ from one another.

100 Due to the limited study of WSII on fine aerosols in northern Zhejiang Province (NZP), 12

101 ionic species $\left(\mathrm{F}^{-}, \mathrm{Cl}^{-}, \mathrm{NO}_{2}{ }^{-}, \mathrm{NO}_{3}{ }^{-}, \mathrm{PO}_{4}{ }^{3-}, \mathrm{SO}_{4}{ }^{2-}, \mathrm{Li}^{+}, \mathrm{Na}^{+}, \mathrm{NH}_{4}{ }^{+}, \mathrm{K}^{+}, \mathrm{Mg}^{2+}, \mathrm{Ca}^{2+}\right)$ from 4 different 102 representative sites in this area located in the southern YRD were investigated, including two 103 urban, one suburban and one rural site. The main objectives of this work were to characterize the 104 temporal and spatial variations of fine aerosols and above mentioned ionic species profiles in $105 \mathrm{NZP}$, compare the ionic chemistry at sites with different urbanization gradients and explore the 106 potential sources of these fine inorganic aerosols in this region.

\section{Experimental}

\subsection{Sampling site}

In order to investigate the ion chemistry of $\mathrm{PM}_{2.5}$ and their possible sources in NZP, different types of representative sampling sites have been selected in both cities of Hangzhou and Ningbo,

111 which are presented in Fig. 1 and briefly introduced as below.

112 1) The University of Nottingham Ningbo, China (UNNC; suburban site; $29.80^{\circ} \mathrm{N}, 121.56^{\circ} \mathrm{E}$ )

113 is located at the University Park in the south of Ningbo city, less than $10 \mathrm{~km}$ away from the 114 central business district (CBD). It can be characterized as an intermediate transition zone which 115 is affected by the pollution from both urban and rural anthropogenic activities. 
2) Ningbo Meteorological Bureau (NMB; urban site; $29.86^{\circ} \mathrm{N}, 121.52^{\circ} \mathrm{E}$ ) is located by the

117 side of a main road- Qixiang Road in Ningbo urban center and adjacent to a high school and

118 residential area. It is also only approximately $1 \mathrm{~km}$ away from the airport highway elevated

119 bridge and 500m from a provincial highway. Therefore, it is expected to be influenced more by 120 traffic emissions.

121 3) Lin'an Regional Atmospheric Background Station (LRABS; rural site; 30.30 N, $\left.122119.73^{\circ} \mathrm{E}\right)$, at the outskirt of Lin'an county within Hangzhou municipality, is a background 123 monitoring station for the World Meteorological Organization (WMO) global atmospheric 124 observation network. It is surrounded by agricultural fields and woods, and less affected by 125 urban, industrial and vehicular emissions.

126 4) Hangzhou Meteorological Bureau (HMB; urban site; $30.22^{\circ} \mathrm{N}, 120.17^{\circ} \mathrm{E}$ ) is one of the 127 national atmospheric and meteorological monitoring stations in China. It is located at the urban 128 center of a densely populated city- Hangzhou, and close to a few heavy traffic roads with 129 distance around $200 \mathrm{~m}$.

\subsection{Sample collection}

131 The collection of $\mathrm{PM}_{2.5}$ was started simultaneously at 9 AM (1 UTC) at four above 132 mentioned sites every 6 days from 12 November 2014 to 12 November 2015. The 24-hour 133 sampling was conducted by medium volume PM2.5 samplers (Model: TH-150CIII, Tianhong 134 Instrument CO., Ltd. Wuhan, China), operating at a flow rate of $80 \mathrm{~L} \mathrm{~min}^{-1}$ and $\mathrm{PM}_{2.5}$ aerosols 135 were captured on $90 \mathrm{~mm}$ quartz fiber filters (QMA, Whatman, UK). All filters were pre-baked in 136 muffle furnace for 5 hours at $550^{\circ} \mathrm{C}$ prior to any other treatments or usage. Blank samples were 137 obtained monthly at four sites. 
2.3. Acquisition of $\mathrm{PM}_{2.5}$ mass, meteorological data and air mass backward trajectories

Prior to any gravimetric measurement, filters were equilibrated in a micro-balance room with constant temperature $\left(22^{\circ} \mathrm{C} \pm 1{ }^{\circ} \mathrm{C}\right)$ and relative humidity $(30 \% \pm 5 \%)$ for $24 \mathrm{~h}$ before and after the sampling events. The $\mathrm{PM}_{2.5}$ mass on $90 \mathrm{~mm}$ quartz fiber filters were measured by an ultramicrobalance (Model: SE2-F, Sartorius, precision $0.1 \mu \mathrm{g}$ ). After that, filters were wrapped in prebaked aluminum foil and stored in refrigerator under $-20^{\circ} \mathrm{C}$ until analysis.

Meteorological data (wind speed, precipitation, temperature and relative humidity) and concentrations of gaseous pollutants $\left(\mathrm{SO}_{2}, \mathrm{NO}_{2}, \mathrm{O}_{3}\right)$ applied in this study were obtained from the corresponding local air quality monitoring stations closest to each sampling site (less than $500 \mathrm{~m}$ distance) during the same aerosol sampling periods.

The air mass backward trajectories were computed from archived global data assimilation system (GDAS1, 2006-present) meteorological data. 96 hours air mass backward trajectories were started at 9:00 AM local time (1 UTC) with 6 hours intervals at a height of $500 \mathrm{~m}$ above ground level (AGL) on each sampling day and calculated separately for each sampling site. Achieved trajectories were then clustered by season using the air resources laboratory (ARL) of National Ocean and Atmospheric Administration (NOAA) Hybrid Single-Particle Integrated Trajectory (HYSPLIT 4.9) model (Draxler, 2013; Rolph, 2013), and those trajectories with similar sources were merged. Clusters can reduce errors that might be related to a single trajectory and indicate more accurate origins of those pollutants.

\subsection{Ionic analysis}

One eighth $90 \mathrm{~mm}$ quartz fiber filters were used for ion analysis, which were extracted ultrasonically using $20 \mathrm{~mL}$ of deionized water for $30 \mathrm{~min}$, filtered with the $0.45 \mu \mathrm{m}$ PTFE microporous membrane and stored in a refrigerator at $4^{\circ} \mathrm{C}$ until chemical analysis within two 
161 weeks. In total, 6 anions $\left(\mathrm{F}^{-}, \mathrm{Cl}^{-}, \mathrm{NO}_{2}^{-}, \mathrm{NO}_{3}^{-}, \mathrm{PO}_{4}{ }^{3-}, \mathrm{SO}_{4}{ }^{2-}\right)$ and 6 cations $\left(\mathrm{Li}^{+}, \mathrm{Na}^{+}, \mathrm{NH}_{4}^{+}, \mathrm{K}^{+}\right.$,

$\left.162 \mathrm{Mg}^{2+}, \mathrm{Ca}^{2+}\right)$ were investigated by Ion Chromatograph (ICS-1600, Dionex, USA). Detailed

163 information about the detection system and methods could be found elsewhere (Xu et al., 2016b).

164 Ion concentrations were calculated through the external calibration $\left(r^{2} \geq 0.99\right)$ with authentic

165 standards purchased from Sigma-Aldrich and corrected by subtracting blank values obtained

166 from field blank samples.

\section{3. Results and discussion}

3.1. Air mass backward trajectory analysis

The air mass backward trajectories are very useful to identify the source origins of the

170 particulate pollutants measured at the sampling sites. Fig. 2 shows the clusters of air mass

171 backward trajectories during each season at different representative sampling sites of NCP, 172 which exhibited distinctive seasonal variations.

173 In winter, clusters at four sites were very similar to each other in this region; $75 \%-97 \%$ of the

174 air masses were coming through northwest and north China before arriving at the sampling sites

175 and part of them were originated from Russia and Kazakhstan. In spring, 13\%-37\% were

176 originated from northwestern Asia; at UNNC and NMB, 20\%-30\% were from northwestern

177 China and the rest were from either a mixed oceanic and terrestrial source or local origins in

178 YRD; at LRABS and HMB, around 50\% of air masses were from central China and local YRD

179 region, respectively. In summer, $45 \%-64 \%$ of the air masses were originated from Chinese Bohai

180 Sea and Pacific Ocean and another part was from South China Sea and passing through southern

181 China to reach the studied sites with both oceanic and terrestrial source characteristics; the rest

$18210-29 \%$ was from the central China. In autumn, the clusters at UNNC and NMB showed similar

183 origins due to their geographical closeness to each other; approximately $40 \%$ of the trajectories 
184 were originated from Russia and Inner Mongolia and the rest were from oceanic origin; at 185 LRABS and HMB, around $20 \%$ of trajectories were coming from north China, the rest were with 186 mixed origins of both ocean and land, among of which 10 20\% were transported through south 187 China to sampling sites.

188 3.2. Spatial and temporal variability of meteorological conditions and $\mathrm{PM}_{2.5}$ concentrations in 189 NZP

190 Continuous hourly measured meteorological data were converted to give daily averaged 191 values from $9 \mathrm{AM}$ on the sampling day to the same time next day. The seasonal mean 192 meteorological parameters (calculated as the daily average of sampling days during each season), 193 including wind speed $\left(\mathrm{m} \mathrm{s}^{-1}\right)$, precipitation $(\mathrm{mm})$, temperature $\left({ }^{\circ} \mathrm{C}\right)$ and relative humidity $(\mathrm{RH}, \%)$ 194 at four sampling sites throughout the sampling campaign are summarized in Table 1.

195 The seasonal averaged temperature and RH at four sampling sites followed the same pattern:

196 Summer $>$ Autumn $>$ Spring $>$ Winter. This is most likely due to the typical marine monsoon 197 subtropical climate in NZP of YRD region, thus all sampling sites in this region are featuring 198 cool dry winters and hot humid summers (Haas and Ban, 2014). The seasonal mean highest 199 temperature in NZP was $26.7^{\circ} \mathrm{C}$ during summer and the lowest was $6.3^{\circ} \mathrm{C}$ during winter. Winter 200 was also recorded as the driest season with $\mathrm{RH}$ of $64.1 \%$ and summer was recognized as the 201 most humid season with RH of $77.8 \%$. The wind speeds of winter, spring and summer were very 202 similar, but that in autumn was obviously lower than the other seasons, implying a more stagnant 203 meteorological condition and weaker advection for dispersion.

204 The annual average $\mathrm{PM}_{2.5}$ concentration in this region (calculated as the average of $\mathrm{PM}_{2.5}$ at

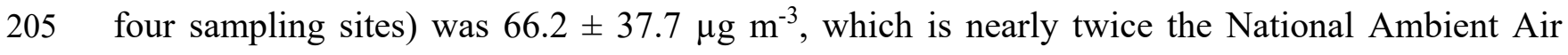
206 Quality Standards of China- Grade II (35 $\mu \mathrm{g} \mathrm{m}^{-3}$ for annual PM2.5 concentration), applicable to 
207 residential, commercial, industrial and rural areas (MEP, 2012). To compare this result with 208 those in other cities of YRD, it is higher than the 3-year average $\mathrm{PM}_{2.5}$ concentration $\left(47 \mu \mathrm{g} \mathrm{m}^{-3}\right)$ 209 measured in Shanghai (Wang et al., 2016c), but comparable with the annual $\mathrm{PM}_{2.5}$ occurrence 210 levels in Hangzhou $\left(64 \pm 47 \mu \mathrm{g} \mathrm{m}^{-3}\right)$ and Nanjing $\left(75 \pm 50 \mu \mathrm{g} \mathrm{m}^{-3}\right)$ (Wang et al., 2014). The 211 annual average concentration of $\mathrm{PM}_{2.5}$ at four sites ranked as: UNNC $\left(51.2 \pm 29.1 \mu \mathrm{g} \mathrm{m}^{-3}\right)<$ 212 LRABS $\left(66.3 \pm 36.6 \mu \mathrm{g} \mathrm{m}^{-3}\right)<\mathrm{NMB}\left(70.4 \pm 40.6 \mu \mathrm{g} \mathrm{m}^{-3}\right)<\mathrm{HMB}\left(80.0 \pm 39.6 \mu \mathrm{g} \mathrm{m}^{-3}\right)$. Clearly, 213 the annual average $\mathrm{PM}_{2.5}$ concentrations in urban sites (NMB \& HMB) were higher than the 214 other two suburban and rural sites (UNNC \& LRABS), possibly indicating stronger 215 anthropogenic sources could contribute more to the higher occurrence levels of fine aerosol 216 particles in urban areas. Among four sites, UNNC was observed with the lowest annual $\mathrm{PM}_{2.5}$ 217 concentration and the highest average wind speed throughout the sampling period. Besides the 218 reasons such as less local emission impact that could be beneficial to the lower occurrence of $219 \mathrm{PM}_{2.5}$ levels at this site, the easier dispersion of aerosol by the stronger wind speed and smoother 220 terrain feature surrounding the sampling site could also be one of them.

The averaged seasonal variations of $\mathrm{PM}_{2.5}$ concentrations at two urban sites (NMB \& HMB) 222 showed the following pattern: Winter $>$ Spring $>$ Autumn $>$ Summer, which is consistent with 223 that in an urban site of Shanghai (Wang et al., 2016c); while the occurrence levels of $\mathrm{PM}_{2.5}$ in 224 suburban and rural sites (UNNC \& LRABS) showed slightly different: Winter > Autumn > 225 Spring $>$ Summer, the same as that observed in a western downtown sampling area in Nanjing 226 of YRD (Li et al., 2015).

227 Among four seasons, the highest average $\mathrm{PM}_{2.5}$ concentration was observed in winter while 228 the lowest in summer. Heavy particle pollution in winter could be the synergetic effect of 229 increased emission from fuel burning and accumulation of pollutants under stagnant weather 
conditions. Lower temperature in winter would lead to the increasing consumption of fuel, such

231 as biomass burning in rural areas and coal combustion in power plants, to meet the increased

232 energy demands for domestic house heating (Behera et al., 2015), resulting in more intensive

233 exhaust of air pollutants (Han et al., 2016). Meanwhile, these air pollutants would accumulate

234 under more calm and static atmospheric environment in winter as this season in this region is

235 normally characteristic of low wind speed, weak solar radiation and strong surface inversion, 236 which would lead to low planetary boundary layer (PBL) height and poor air dispersion (Behera 237 et al., 2015; Seidel et al., 2010). While in summer, wind mostly blows from the East China Sea 238 where less polluted air mass is transported to YRD; in addition, higher mixing layer during hot 239 summer could induce stronger vertical diffusion and dispersion of air pollutants.

240 It is noteworthy that the seasonal averaged $\mathrm{PM}_{2.5}$ concentrations in autumn were lower than 241 those in spring of two urban sites (NMB and HMB), but they were opposite at the other two 242 suburb and rural sites. These findings could be the result of various wet precipitation rates during 243 the different seasons and stronger precipitation favored to increase the scavenging of aerosols. In 244 addition, at suburban and rural sites, more open burning events for land clearing tend to occur 245 during autumn harvest season, mainly in October and November (Yin et al., 2017). Therefore, at 246 UNNC and LRABS, more emissions from biomass burning were expected to contribute to the 247 higher $\mathrm{PM}_{2.5}$ concentrations in autumn than in spring.

248 3.3. Characteristics of water-soluble inorganic ions (WSII)

\subsubsection{Annual occurrence level of total WSII}

250 The annual average concentration of total WSII in NZP was $29.1 \pm 19.9 \mu \mathrm{g} \mathrm{m}^{-3}$, constituting $25144.0 \%$ of the annual average PM 2.5 concentration. Sulfate, nitrate and ammonium (SNA) ranked 252 as the top three ions with highest concentrations in this study, and the sum of them was $25.6 \pm$ 
$25318.4 \mu \mathrm{g} \mathrm{m}^{-3}$, accounting for $88.0 \%$ of total WSII and $38.7 \%$ of $\mathrm{PM}_{2.5}$ concentration in this region, 254 respectively.

255 In order to better understand the fine aerosol pollution in YRD, intra- and inter-city 256 comparisons have been conducted as presented in Table 2 and other polluted areas in China 257 including North China Plain (NCP), Northwest China (NWC) and Pearl River Delta (PRD).

258 Cities in NCP such as Handan, Hefei and Tianjin were observed with much higher PM2.5 and 259 total WSII concentrations, but the mass ratio of WSII in $\mathrm{PM}_{2.5}$ is comparable to those found in 260 this study (Deng et al., 2015; Meng et al., 2016; Zhou et al., 2016). In addition to the effects of 261 stagnant meteorological conditions leading to high accumulation or trans-boundary transport of 262 pollutants originated from other regions, it seems that the aerosol pollution in different regions 263 also have its own characteristics. Higher particle pollution level in NCP is most likely due to the 264 numerous anthropogenic emissions from heavy industries and strong traffic emissions in this 265 region, as a result of its rapid population growth and economic development in past few decades 266 (Ran et al., 2016). Cities like Xi' an and Weinan in NWC were also observed with higher aerosol 267 concentrations, but the one in $\mathrm{Xi}$ 'an had a relatively lower WSII/PM2.5 ratio compared to this 268 study (Niu et al., 2016; Zhang et al., 2011), which might be due to its higher mineral dust 269 contribution as it occurs frequently in this area (Zhang et al., 2011). The occurrence levels of fine 270 aerosols in urban PRD area seem very comparable to those in this study (Tao et al., 2009; Zhou 271 et al., 2016). In Shanghai a two-year (2012-2013) sampling campaign found out that the average $272 \mathrm{PM}_{2.5}$ concentration was lower than those reported in other cities in YRD, but WSII/PM 2.5 ratio 273 was over $60 \%$ indicating a strong contribution of secondary inorganic ions to fine aerosols in this 274 urban area (Wang et al., 2016c). 
The annual total WSII concentrations at four sampling sites followed such an order: UNNC $\left(21.0 \pm 10.8 \mu \mathrm{g} \mathrm{m}^{-3}\right)<\operatorname{NMB}\left(26.7 \pm 18.8 \mu \mathrm{g} \mathrm{m}^{-3}\right)<\operatorname{LRABS}\left(29.6 \pm 18.2 \mu \mathrm{g} \mathrm{m}^{-3}\right)<\mathrm{HMB}(41.3 \pm$ $25.5 \mu \mathrm{g} \mathrm{m}^{-3}$ ), contributed to $38.6 \% \sim 49.2 \%$ of $\mathrm{PM}_{2.5}$, as shown in Table 2. Similar to the occurrence levels of $\mathrm{PM}_{2.5}$ and WSII, SNA exhibited much higher concentrations in NCP and NWC than those in this study, which however seemed comparable to the reported values in YRD and PRD. The annual SNA concentration at UNNC, the suburban site of Ningbo, was $17.4 \mu \mathrm{g} \mathrm{\textrm {m } ^ { - }}$ ${ }^{3}$, accounting for $81.9 \%$ of total WSII concentration and $35.8 \%$ of $\mathrm{PM}_{2.5}$; while at NMB, the 283 urban site of Ningbo, higher annual SNA concentration of $23.0 \mu \mathrm{g} \mathrm{m}^{-3}$ was observed with higher mass ratio of $83.3 \%$ in total WSII but lower proportion of $32.9 \%$ in $\mathrm{PM}_{2.5}$. Higher annual SNA concentrations of $27.2 \mu \mathrm{g} \mathrm{m}^{-3}\left(90.5 \%\right.$ of total WSII concentration and $40.5 \%$ of $\left.\mathrm{PM}_{2.5}\right)$ and 37.0 $\mu \mathrm{g} \mathrm{m}^{-3}\left(88.8 \%\right.$ of total WSII concentration and $44.5 \%$ of $\left.\mathrm{PM}_{2.5}\right)$ were observed at LRABS and HMB in Hangzhou, respectively, suggesting the secondary aerosol formations at both sites were more significant than Ningbo.

Table 3 illustrates the seasonal and annual averaged WSII concentrations at four sampling sites. Among the investigated ions at all sites, $\mathrm{NH}_{4}^{+}, \mathrm{NO}_{3}{ }^{-}, \mathrm{SO}_{4}{ }^{2-}$ and $\mathrm{Cl}^{-}$were of predominance 291 and the first three are known to be the dominant secondary particles with their abundances 292 mainly dependent on the concentrations of their precursor gases and transformation rates. As 293 shown in Table 3, winter was observed with the highest ionic concentrations while summer was 294 observed with the lowest. The concentrations of both ammonium and nitrate in winter were $2 \sim 6$ 295 times higher than those in summer. This could be related to the low temperature in winter that 296 favors a conversion from nitric acid and ammonia gases to the particulate ammonium nitrate and 297 also that most nitrate would prefer to be gaseous at temperature higher than $30^{\circ} \mathrm{C}$ (Deng et al., 
2015). The seasonal variation of nitrate concentration could also be attributed to the seasonality of $\mathrm{NO}_{\mathrm{x}}$ emission ( $\mathrm{Li}$ and $\mathrm{Han}, 2016$ ). It is known that both $\mathrm{HCl}$ and $\mathrm{SO}_{2}$ are the typical pollutants emitted from coal combustion (Xue et al., 2016); hence, the highest abundance of both sulfate and chloride in winter could be likely due to the increased coal consumption during heating period combined with poor dispersion (He et al., 2001). In addition to the local emissions, during winter in YRD, the prevalent north or northwest winds can bring atmospheric pollutants from $\mathrm{NCP}$, where more consumption of coal for domestic heating also occurs in this season (Wang et al., 2016c), to the sampling sites in this study via long-range transport, which was supported by air mass backward trajectory analysis in Section 3.1 that $75 \%-97 \%$ of the air masses were coming through northwest and north China before arriving at the sampling sites.

Apart from $\mathrm{NH}_{4}{ }^{+}, \mathrm{Cl}^{-}, \mathrm{NO}_{3}{ }^{-}$and $\mathrm{SO}_{4}{ }^{2-}$, the concentration of $\mathrm{K}^{+}$was the highest among the rest ions. The highest concentration of $\mathrm{K}^{+}$occurred in winter as well, it is around 2 4 times higher 310 than summer at four sites. As it is predominantly generated from biomass burning, such as wood, 311 grass and crop straw burning (Xu et al., 2016b), suggesting biomass burning is an important 312 contributor to the fine particles in the NZP, which can be supported by the high level of non-sea 313 salt (nss) $\mathrm{K}^{+}$during winter $\left(1.0 \mu \mathrm{g} \mathrm{m}^{-3}\right)$ and spring $\left(0.9 \mu \mathrm{g} \mathrm{m}^{-3}\right)$ in a rural site- LRABS. 
Where, $\mathrm{F}^{-}, \mathrm{Cl}^{-}, \mathrm{NO}_{2}{ }^{-}, \mathrm{NO}_{3}{ }^{-}, \mathrm{PO}_{4}{ }^{3-}, \mathrm{SO}_{4}{ }^{2-}, \mathrm{Li}^{+}, \mathrm{Na}^{+}, \mathrm{NH}_{4}^{+}, \mathrm{K}^{+}, \mathrm{Mg}^{2+}$, and $\mathrm{Ca}^{2+}$ refer to their mass concentrations $\left(\mu \mathrm{g} \mathrm{m}^{-3}\right)$. Through calculations by the above equations, the anion and cation concentrations $\left(\mu \mathrm{g} \mathrm{m}^{-3}\right)$ were converted into their corresponding micro-equivalents $\left(\mu \mathrm{mol} \mathrm{m}^{-3}\right)$ and the relationships between $\mathrm{AE}$ and $\mathrm{CE}$ in four seasons of the sampling sites are plotted in Fig. 3.

As shown in Fig. 3, good correlations and very small intercepts between AE and CE were 328 found in 4 seasons; therefore, the anion/cation equivalent ratios (AE/CE) were defined as the 329 slopes of linear regressions in this study. At 4 sites, the correlation coefficients of AE and CE 330 were in the range of $0.77 \sim 0.99$, similar to the results in another study of YRD $(0.72 \sim 0.94)$ (Wang 331 et al., 2015a). At UNNC and HMB, the AE/CE ratios in four seasons were mostly above 1.0, 332 except the ratio close to 1 in the summer of UNNC. These results indicated a deficiency in 333 cations of $\mathrm{PM}_{2.5}$ samples in $\mathrm{UNNC}$ and $\mathrm{HMB}$, anions were not fully neutralized and caused 334 acidic nature of fine particles at these two sites. When using the equivalent ratio of $\left[\mathrm{NH}_{4}{ }^{+}\right] /$ $335\left[\mathrm{NO}_{3}{ }^{-} \mathrm{SO}_{4}{ }^{2-}\right]$ to evaluate the aerosol acidity (Wang et al., 2016a), the ratio at HMB was 0.99, 336 indicating a good neutralization relationship between the major secondary species at this site 337 during the sampling period. At UNNC, the annual averaged equivalent ratio of $\left[\mathrm{NH}_{4}^{+}\right] /\left[\mathrm{NO}_{3}{ }^{-}\right.$ $\left.338+\mathrm{SO}_{4}{ }^{2-}\right]$ was only 0.89 , while the annual averaged equivalent ratio of $\left[\mathrm{NH}_{4}{ }^{+}+\mathrm{Ca}^{2+}\right] /\left[\mathrm{NO}_{3}{ }^{-}+\mathrm{SO}_{4}{ }^{2-}\right]$ 339 of UNNC could be up to 0.98 , suggesting $\mathrm{Ca}^{2+}$ might be another main cation affecting the 340 neutralization of $\mathrm{NO}_{3}{ }^{-}$and $\mathrm{SO}_{4}{ }^{2-}$. This could be explained by the fact that a number of 341 construction sites existed around UNNC during this sampling campaign, which might be the 342 dominant sources of $\mathrm{Ca}^{2+}$ at this site showing strong influence on the ionic chemistry here. 
In LRABS, during winter and spring, it had lower $\mathrm{AE} / \mathrm{CE}$ value $(<1)$ and the seasonal

344 averaged equivalent ratio of $\left[\mathrm{NH}_{4}{ }^{+}\right] /\left[\mathrm{NO}_{3}{ }^{-}+\mathrm{SO}_{4}{ }^{2-}\right]$ of winter and spring were 1.13 and 1.36 , 345 respectively, implying the aerosol samples during these two seasons were alkaline, probably due 346 to the increased biomass burning in winter and more usage of ammonia containing fertilizer in 347 spring for cultivation at this rural site (Whitburn et al., 2015). The aerosol collected in autumn at 348 Lin'an had shown higher AE/CE ratio (=1.09), indicating these aerosols were more acidic, which 349 could be attributed to the higher occurrence level of $\mathrm{NO}_{3}{ }^{-}$in autumn, which was 2.8 times that 350 during summer when ammonium nitrate is more easily volatilized as mentioned before. The $351 \mathrm{AE} / \mathrm{CE}$ ratio during summer at Lin'an was close to 1 and the averaged equivalent ratio of $352\left[\mathrm{NH}_{4}^{+}\right] /\left[\mathrm{NO}_{3}{ }^{-}+\mathrm{SO}_{4}{ }^{2-}\right]$ was 0.95 , indicating anions and cation maintained a good neutralization 353 relationship.

354 The AE/CE slope of the linear regression for NMB were all lower than 0.9 in the whole 355 sampling campaign; since most of the anions were analyzed but not the carbonate and 356 bicarbonate due to the limitation of the Ion Chromatogram (IC) method, the anion deficits in 357 aerosol samples of NMB could be partially attributed to the absence of both ions (Meng et al., 358 2016). The annual averaged equivalent ratio of $\left[\mathrm{NH}_{4}{ }^{+}\right] /\left[\mathrm{NO}_{3}{ }^{-}+\mathrm{SO}_{4}{ }^{2-}\right]$ of $\mathrm{NMB}$ was 1.11 , also 359 suggesting $\mathrm{NH}_{4}{ }^{+}$was over-sufficient to neutralize $\mathrm{NO}_{3}{ }^{-}$and $\mathrm{SO}_{4}{ }^{2-}$. The excess of $\mathrm{NH}_{4}{ }^{+}$could be 360 associated with anions like chloride and carbonate. Moreover, since NMB is located by the side 361 of a main road and near a couple of highways, it is expected to be influenced heavily by traffic 362 emissions, an important source of urban $\mathrm{NH}_{3}$ derived from urea used in the selective catalytic 363 reduction (SCR) in vehicular engines (Pan et al., 2016), which seems supported by the higher 364 annual concentration of $\mathrm{NH}_{4}^{+}$at urban site $\mathrm{NMB}\left(6.6 \mu \mathrm{g} \mathrm{m}{ }^{-3}\right)$ than suburban site UNNC $(3.9 \mu \mathrm{g}$ $365 \mathrm{~m}^{-3}$ ) in Ningbo. 
In order to further find out the significance of each cation in neutralizing aerosol acidity, the neutralization capacities of major cations (nss- $\mathrm{Ca}^{2+}, \mathrm{Mg}^{2+}$, nss- $\mathrm{K}^{+}$and $\mathrm{NH}_{4}^{+}$) were individually 369 estimated by applying the Neutralization Factors (NFs). $\mathrm{SO}_{4}{ }^{2-}$ and $\mathrm{NO}_{3}{ }^{-}$were considered as the 370 dominant acidifying anions. $\mathrm{Na}^{+}$and $\mathrm{Cl}^{-}$were considered negligible in past few studies for 371 calculation of NF, as they existed mostly in the form of neutral sea salt (Safai et al., 2010; 372 Satsangi et al., 2013). However, in this study, poor correlation of $\mathrm{Na}^{+}$and $\mathrm{Cl}^{-}\left(\mathrm{r}^{2}<0.5\right)$ were 373 found at all four sites, suggesting possible different origins of $\mathrm{Cl}^{-}$. Moreover, the $\mathrm{Na}^{+} / \mathrm{Cl}^{-}$ 374 equivalent ratios of UNNC, NMB, LRABS and HMB were 0.47, 0.53, 0.91 and 0.51 , 375 respectively, lower than that in seawater (1.1) (Xu et al., 2014), implying $\mathrm{Cl}^{-}$could also have 376 other sources such as coal combustion and waste incineration in addition to sea salt (Xue et al., 377 2016). LRABS had the highest $\mathrm{Na}^{+} / \mathrm{Cl}^{-}$equivalent ratio (0.91) and lowest $\mathrm{Cl}^{-} / \mathrm{PM}_{2.5}$ mass ratio $378(0.9 \%)$ among four sites (HMB: 1.8\%; NMB: 2.2\%; UNNC: $2.9 \%)$, suggesting relatively more 379 marine effect yet less contribution of other combustion processes at this rural site. Therefore, the 380 role of $\mathrm{Cl}^{-}$in neutralization could not be neglected in this study. As $\mathrm{Na}^{+}$was assumed to be all 381 derived from the ocean (Kong et al., 2014), and it predominantly existed as $\mathrm{NaCl}$ in sea salts 382 (Ueda et al., 2014), hence non-sea salt $\left[\mathrm{Cl}^{-}\right]$can be calculated by subtracting $\left[\mathrm{Na}^{+}\right]$from $\left[\mathrm{Cl}^{-}\right]$and 383 NFs were calculated by Equation (3-6):

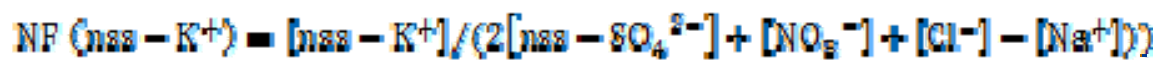


$[\mathrm{X}]$ represents the molar concentration of ions, and $\mathrm{nss}-\mathrm{SO}_{4}{ }^{2-}, \mathrm{nss}^{-} \mathrm{K}^{+}$and $\mathrm{nss}^{-\mathrm{Ca}^{2+}}$ were estimated in section 3.4.1.

Fig. 4 depicts the NFs of nss- $\mathrm{Ca}^{2+}, \mathrm{Mg}^{2+}$, nss- ${ }^{+}$and $\mathrm{NH}_{4}^{+}$in $\mathrm{PM}_{2.5}$ at 4 sites of northern 391 Zhejiang Province. As expected, $\mathrm{NH}_{4}^{+}$was the predominant neutralizing cation with the highest $392 \mathrm{NF}$, and the average annual $\mathrm{NF}$ of $\mathrm{NH}_{4}{ }^{+}$at 4 sites were LRABS (1.12) $>\mathrm{NMB}(1.08)>\mathrm{HMB}$ $393(0.95)>$ UNNC (0.83). The annual NF of $\mathrm{NH}_{4}{ }^{+}$in LRABS and NMB were above 1, indicating 394 the excess of $\mathrm{NH}_{4}{ }^{+}$after neutralizing nss- $\mathrm{SO}_{4}{ }^{2-}, \mathrm{NO}_{3}{ }^{-}$and $\mathrm{Cl}^{-}$, which might also be explained by 395 those reasons discussed in Section 3.3.3 for part of AE/CE ratios smaller than unity at these two 396 sites. The NF values of $\mathrm{nss}-\mathrm{Ca}^{2+}, \mathrm{nss}-\mathrm{K}^{+}$and $\mathrm{Mg}^{2+}$ were lower than 0.2 , implying relatively 397 minor impact of these ions in the neutralization of aerosol acidity. On an annual basis, the

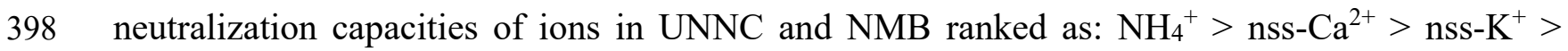
$399 \mathrm{Mg}^{2+}$. Nss-Ca ${ }^{2+}$ was the second dominant neutralizing cation at both sites of Ningbo, possibly 400 due to the strong dust effect from the nearby construction areas and main roads as discussed 401 before. In LRABS, the annual averaged NF of nss- $\mathrm{K}^{+}$was the second highest after $\mathrm{NH}_{4}^{+}$, which 402 is reasonable since biomass burning is a common activity in rural area for land clearance and 403 house heating possibly to contribute more nss- $\mathrm{K}^{+}$to the local atmosphere. In HMB, NFs of nss$404 \mathrm{~K}^{+}$during both winter and autumn were the second highest among four cations, possibly due to 405 the enhanced local biomass burning for house heating in winter and open crop residue burning in 406 autumn (Chen et al., 2016). Additionally, as shown in Fig. 2, the majority of air masses reaching 407 HMB were coming through highly polluted NCP, rural site- LRABS (located at the northwest of 408 HMB) and agriculture lands dominated western and northern suburban areas of Hangzhou 409 (Sheng et al., 2017), hence, elevated $\mathrm{K}^{+}$could be expected at HMB due to medium- and short410 range transport. 
3.4.1. Marine contribution of the aerosol composition

As located at the east coast of China, bordering the East China Sea and Yellow Sea, marine

414 effects seemed not to be ignored in this work. Therefore, the non-sea salt (Toledano et al., 2012)

415 contribution to aerosols has been evaluated. $\mathrm{Na}^{+}$was assumed to be all derived from the sea and 416 non-sea salts were calculated using following equation (Kong et al., 2014):

$$
n 8 s-X=X_{1}-\mathrm{Na}_{1}^{+} \times\left(\mathrm{X} / \mathrm{Na}^{+}\right)_{\mathrm{sea}}
$$
$\left(\mathrm{X} / \mathrm{Na}^{+}\right)_{\text {sea }}$ is ratio of ion and $\mathrm{Na}^{+}$in seawater. The $\left(\mathrm{X} / \mathrm{Na}^{+}\right)_{\text {sea }}$ ratios for $\mathrm{Ca}^{2+}, \mathrm{K}^{+}$and $\mathrm{SO}_{4}{ }^{2-}$ are 0.0385, 0.037 and 0.2516, respectively, based on the seawater composition (Balasubramanian et 421 al., 2003). $/ \mathrm{SO}_{4}{ }^{2-}, \mathrm{nss}-\mathrm{K}^{+} / \mathrm{K}^{+}$and $\mathrm{nss}-\mathrm{Ca}^{2+} / \mathrm{Ca}^{2+}$ ratios. High ratios $(\geq 0.86)$ of $\mathrm{nss}-\mathrm{SO}_{4}{ }^{2-} / \mathrm{SO}_{4}{ }^{2-}, \mathrm{nss}^{-} \mathrm{K}^{+} / \mathrm{K}^{+}$ 424 and nss- $\mathrm{Ca}^{2+} / \mathrm{Ca}^{2+}$ were found at all four sites, indicating minor marine contribution $(\leq 14 \%)$ to 425 these ions. In LRABS and $\mathrm{HMB}$, the nss- $\mathrm{SO}_{4}{ }^{2-} / \mathrm{SO}_{4}{ }^{2-}$ of all seasons was up to 0.99 , indicating the 426 marine influence on sulfate concentration is negligible. The trend of nss- $\mathrm{SO}_{4}{ }^{2-} / \mathrm{SO}_{4}{ }^{2-}$ during all 427 seasons in UNNC and NMB were quite similar and the ratios in winter, spring and autumn were 428 around 0.98-0.99; while marine source affected UNNC and NMB more in summer with a contribution of non-sea salt to total sulphate up to $97 \%$, which could be attributed to the slightly 430 elevated air mass from the sea compared to the other two sites, as shown in the trajectory clusters 431 of Fig. 2.

$432 \quad$ Nss- $\mathrm{K}^{+}$has been revealed as a tracer of biomass burning (Chow et al., 2004), the nss-K 433 concentration in winter were more than twice that in summer and the highest nss- $\mathrm{K}^{+} / \mathrm{K}^{+}$also 
434 occurred in winter at all four sites, indicating the heaviest biomass burning contribution to the 435 high level of fine particles in winter and minimum marine influence while most significant 436 biomass burning impact on $\mathrm{K}^{+}$during this season. Relatively higher nss- $\mathrm{K}^{+}$in autumn and spring 437 could also be the result of biomass burning during these two seasons, especially the straw 438 burning during both harvest periods in this region. However, in the summer at UNNC and NMB, 439 more sea salt contribution to $\mathrm{K}^{+}$with lowest nss- $\mathrm{K}^{+} / \mathrm{K}^{+}$was observed, possibly due to the 440 stronger air masses transported from oceanic origins in this season. The high value of nss$441 \mathrm{Ca}^{2+} / \mathrm{Ca}^{2+}$ indicate $\mathrm{Ca}^{2+}$ was not majorly related to marine origin but more of continental 442 contribution.

\subsubsection{Correlations between WSIIs}

The correlation between WSII mass concentrations is a good way to investigate the possible 445 sources and associations among various ionic species. Correlation results, shown as the 446 correlation coefficients (r), are provided in Supplemental Table S1-S16.

447 The secondary species, ammonium sulfate $\left(\left(\mathrm{NH}_{4}\right)_{2} \mathrm{SO}_{4}\right)$, ammonium bi-sulfate $\left(\mathrm{NH}_{4} \mathrm{HSO}_{4}\right)$ 448 and ammonium nitrate $\left(\mathrm{NH}_{4} \mathrm{NO}_{3}\right)$, namely secondary inorganic aerosol (SIA), are generated 449 through both homogeneous and heterogeneous reactions of gaseous precursors $\left(\mathrm{SO}_{2}, \mathrm{NO}_{2}, \mathrm{NH}_{3}\right)$. 450 Their formation depends on the availability of their corresponding precursor gases and the 451 atmospheric conditions. It is reported that ammonia would first neutralize with sulphuric acid to 452 form $\mathrm{NH}_{4} \mathrm{HSO}_{4}$ and $\left(\mathrm{NH}_{4}\right)_{2} \mathrm{SO}_{4}$, then the remaining ammonia would react with nitric acid to 453 generate $\mathrm{NH}_{4} \mathrm{NO}_{3}$ (Squizzato et al., 2012). $\mathrm{NH}_{4}{ }^{+}$was found out significantly correlated with $454 \mathrm{NO}_{3}^{-}$and $\mathrm{SO}_{4}^{2-}$ throughout the sampling period at 4 sites, and most of their correlation 455 coefficients were in the range of $0.80 \sim 0.99$; moreover, the annual averaged molar ratio of

$456\left[\mathrm{NH}_{4}^{+}\right] /\left[\mathrm{SO}_{4}{ }^{2-}\right]$ at 4 sites were above 3.3 , indicating the coexistence of $\left(\mathrm{NH}_{4}\right) \mathrm{HSO}_{4},\left(\mathrm{NH}_{4}\right)_{2} \mathrm{SO}_{4}$ 
and $\mathrm{NH}_{4} \mathrm{NO}_{3}$. Higher correlations between $\mathrm{NH}_{4}{ }^{+}$and $\mathrm{SO}_{4}{ }^{2-}$ than $\mathrm{NH}_{4}{ }^{+}$and $\mathrm{NO}_{3}{ }^{-}$were found in summer at 4 sites, indicating the primary formation of sulfates instead of nitrates during the summer in NZP, which is also supported by the molar ratio of $\left[\mathrm{NH}_{4}{ }^{+}\right] /\left[\mathrm{SO}_{4}{ }^{2-}\right]$ with an average of 2.2 throughout the summer at all sites.

In winter, except the strong correlations between major secondary ionic species, $\mathrm{NO}_{2}^{-}$was found to correlate highly with $\mathrm{Mg}^{2+}(\mathrm{r}=0.80)$ and $\mathrm{Ca}^{2+}(\mathrm{r}=0.88)$ in UNNC (Table S1), implying the major existence of $\mathrm{NO}_{2}{ }^{-}$was $\mathrm{Mg}\left(\mathrm{NO}_{2}\right)_{2}$ and $\mathrm{Ca}\left(\mathrm{NO}_{2}\right)_{2}$. Since it has been reported that $\mathrm{NO}_{2}{ }^{-}$ can be formed through heterogeneous conversion of $\mathrm{NO}_{2}$ on wet particle surface (Wang et al., 2015b), good correlations between $\mathrm{NO}_{2}{ }^{-}$and $\mathrm{Mg}^{2+}$ and $\mathrm{Ca}^{2+}$ could possibly be due to the efficient conversion from $\mathrm{NO}_{2}$ to $\mathrm{NO}_{2}{ }^{-}$on these mineral particles. $\mathrm{Mg}^{2+}$ and $\mathrm{Ca}^{2+}$ was found to correlate well $(\mathrm{r}=0.85)$ in winter at Lin'an (Table S9), likely attributed to their common sources such as soil dust from the surrounding agricultural environment under dry and windy condition during winter (Satsangi et al., 2013). The ratio of $\mathrm{Mg}^{2+} / \mathrm{Ca}^{2+}$ is 0.34 during winter in Lin'an, higher than 0.12 in sea salt aerosol (Deng et al., 2015), reconfirming sea salt was not a major contributor. As mentioned before, $\mathrm{K}^{+}$is treated as a tracer for biomass or biofuel emissions, which is observed to correlate well with $\mathrm{PM}_{2.5}$ in Lin'an $(\mathrm{r}=0.84)$ (Table S9) and Hangzhou $(\mathrm{r}=$ 0.88) (Table S13), indicating the significant contributions from biomass burning to the occurrence levels of aerosol at these two sites. Since biomass burning is reported as the second largest emission source of $\mathrm{NH}_{3}$ from land clearing activity (Whitburn et al., 2015), good correlations between $\mathrm{K}^{+}$and $\mathrm{NH}_{4}^{+}(\mathrm{r}=0.80$, Table S13) also supported the above statement on contribution of biomass burning to high aerosol concentrations at Hangzhou.

In spring at $\mathrm{UNNC}, \mathrm{K}^{+}$and $\mathrm{NH}_{4}^{+}(\mathrm{r}=0.82), \mathrm{Cl}^{-}$and $\mathrm{NO}_{2}^{-}(\mathrm{r}=0.87)$ were also found correlated (Table S2), suggesting their common source like coal combustion and biomass 
burning (Pei et al., 2016; Whitburn et al., 2015). Even though $\mathrm{Na}^{+}$and $\mathrm{Cl}^{-}$correlated very well (r $481=0.88$ ), the equivalent ratio of $\mathrm{Na}^{+} / \mathrm{Cl}^{-}$was only 0.44 , much lower than their equivalent ratio in

seawater (1.1), suggesting marine source was only one of its major origins and regional soil could also be partially responsible for their tight correlation ( $\mathrm{Xu}$ et al., 2014). As $\mathrm{NOx}$ is also emitted from biomass burning (Chen et al., 2016), good correlations ( $\mathrm{r}=0.83$ and 0.87 , respectively, Table S10) between $\mathrm{K}^{+}$and $\mathrm{NO}_{3}{ }^{-}$may imply their common source of biomass burning at NMB and Lin'an. In Hangzhou (Table S14), $\mathrm{Mg}^{2+}$ correlated with $\mathrm{Ca}^{2+}(\mathrm{r}=0.85)$ and $\mathrm{NO}_{2}^{-}(\mathrm{r}=0.81)$, which might be due to the efficient heterogeneous conversion of $\mathrm{NO}_{2}$ to $\mathrm{NO}_{2}{ }^{-}$ on mineral surface as explained, which is also supported by the highest concentration of $\mathrm{Ca}^{2+}$ in spring of $\mathrm{HMB}$. High correlation between $\mathrm{Cl}^{-}$and $\mathrm{NO}_{3}^{-}(\mathrm{r}=0.84)$ suggested their common sources such as coal combustion and waste incineration (Pei et al., 2016).

In summer, no tight correlations were found among these ions in Ningbo and Lin'an, apart from SNA. While in summer of Hangzhou (Table S15), in addition to that, $\mathrm{K}^{+}$correlated very well with $\mathrm{Cl}^{-}(\mathrm{r}=0.90)$ and $\mathrm{SO}_{4}{ }^{2-}(\mathrm{r}=0.88)$, and $\mathrm{Cl}^{-}$also correlated well with $\mathrm{NO}_{3}^{-}(\mathrm{r}=0.83)$ and $\mathrm{SO}_{4}^{2-}(\mathrm{r}=0.80)$, indicating they may share part of the combustion related sources including fossil fuel combustion, waste incineration and biomass burning, etc.

In autumn in this region, $\mathrm{K}^{+}$is found to correlate very well with $\mathrm{PM}_{2.5}, \mathrm{NO}_{3}{ }^{-}$and $\mathrm{NH}_{4}{ }^{+}$at all sampling sites $(r>0.80)$ (Table S4, S8, S12, S16). As discussed above, in this season these components could be affected heavily by agricultural activities (livestock waste volatilization and nitrogen containing fertilizer) as well as land clearing practice. Besides, high correlations of $\mathrm{Na}^{+}$and $\mathrm{Cl}^{-}(\mathrm{r}=0.80), \mathrm{Ca}^{2+}$ and $\mathrm{NO}_{2}^{-}(0.88)$ were observed in $\mathrm{HMB}$ (Table $\left.\mathrm{S} 16\right) . \mathrm{Na}^{+}$is also found to correlate well with $\mathrm{NO}_{2}^{-}(\mathrm{r}=0.87)$ at $\mathrm{UNNC}$ (Table $\left.\mathrm{S} 4\right)$, and $\mathrm{K}^{+}$is found to correlate with both primary $\mathrm{Ca}^{2+}(\mathrm{r}=0.80)$ and secondary $\mathrm{SO}_{4}^{2-}(\mathrm{r}=0.87)$ in NMB (Table S8), possibly 
503 due to the similar transport pathways of air masses or mixture of both primary and secondary

504 aerosols (Xu et al., 2014).

505 3.4.3. Chemical conversions of species- sulfur and nitrogen oxidation ratios

506 The oxidation of $\mathrm{SO}_{2}-\mathrm{SO}_{4}{ }^{2-}$ and $\mathrm{NO}_{2}-\mathrm{NO}_{3}^{-}$has two mechanisms: homogeneous and 507 heterogeneous reactions (Liu et al., 2016). The former involves gas-phase $\mathrm{SO}_{2}$ and $\mathrm{NO}_{2}$ 508 oxidation reactions with $\mathrm{OH} \bullet$ radical; the latter for $\mathrm{SO}_{2}-\mathrm{SO}_{4}{ }^{2-}$ transformation includes $\mathrm{H}_{2} \mathrm{O}_{2} / \mathrm{O}_{3}$ 509 oxidation or metal catalyzed sulfur and in-cloud process, closely associated with RH and aerosol 510 mass concentration (Wang et al., 2006), and heterogeneous reactions for $\mathrm{NO}_{2}-\mathrm{NO}_{3}^{-}$is the 511 hydrolysis of $\mathrm{N}_{2} \mathrm{O}_{5}$ on pre-existing particulate matter, such as sulfate aerosols (Meng et al., 2016; 512 Zhang et al., 1995). Therefore, to investigate the conversion of above species in this study, sulfur 513 oxidation ratio (SOR) and nitrogen oxidation ratio (Xie et al.) were applied and they are 514 caculated as follows (Lin, 2002): higher SOR and NOR indicate greater oxidation of $\mathrm{SO}_{2}$ and $\mathrm{NO}_{2}$, and more secondary aerosols would be produced. The seasonal averaged $\mathrm{SO}_{2}, \mathrm{NO}_{2}, \mathrm{O}_{3}$ concentrations and $\mathrm{SOR}$, NOR values 520 at four sampling sites during the sampling campaign are presented in Supplemental Table S17.

521 It has been reported the photochemical oxidation of $\mathrm{SO}_{2}$ to $\mathrm{SO}_{4}^{2-}$ could occur when 522 SOR $>0.1$ (Ohta and Okita, 1990). The SOR values of all seasons at the 4 sampling sites were 523 above 0.1 , indicating the oxidation of $\mathrm{SO}_{2}$ occurred throughout the whole sampling campaign in 524 NZP. In four seasons, summer was observed with the highest SOR values at all sampling sites, 525 suggesting a considerable conversion of $\mathrm{SO}_{2}$ to sulfate. As the homogeneous reaction of $\mathrm{SO}_{2}$ and 
$\mathrm{OH} \bullet$ radical is a strong function of solar irradiation and ambient temperature (Meng et al., 2016),

527 homogeneous transition of $\mathrm{SO}_{2}-\mathrm{SO}_{4}{ }^{2-}$ may have contributed to the highest $\mathrm{SOR}$ in hot summer.

528 High presence of $\mathrm{O}_{3}$ in summer may have also helped the oxidation of $\mathrm{SO}_{2}$ (Meng et al., 2016).

529 Additionally, more efficient heterogeneous aqueous reaction of $\mathrm{SO}_{2}$ and $\mathrm{NO}_{2}$ could also occur 530 under high RH in summer to generate sulfate and gas-phase HONO significantly (Wang et al., 531 2016a). It is noteworthy that the highest $\mathrm{SOR}$ value and lowest $\mathrm{SO}_{2}$ concnetration were observed 532 simultaneously during the summer at all sites in NZP, very possibily due to 1) strong oxidation 533 of $\mathrm{SO}_{2}$ to $\mathrm{SO}_{4}^{2-} ; 2$ ) the highest precipitation rate favorable for the efficient scavenging of $\mathrm{SO}_{2}$ 534 and 3) high PBL height during the summer beneficial to dispersion of $\mathrm{SO}_{2}$. The $\mathrm{SOR}$ in other 535 seasons ranked as autumn $>$ spring $>$ winter. Lowest SOR in highly polluted winter could be 536 caused by: 1) the intensive emission of $\mathrm{SO}_{2}$ from enhanced coal combustion, which was inclined 537 to be accumulated greatly under stagnant weather condition during cold winter with poor air 538 dispersion and circulation; 2) under stagnant weather, low solar radiation reduced the 539 photochemical activity which could not provide sufficient oxidants and hindered the 540 homogeneous reaction of $\mathrm{SO}_{2}-\mathrm{SO}_{4}{ }^{2-}$ (Hua et al., 2008; Liu et al., 2016); 3) lowest $\mathrm{RH}$ reduced 541 the possibility of heterogeneous aqueous reaction of $\mathrm{SO}_{2}-\mathrm{SO}_{4}{ }^{2-}$, and eventually caused the 542 lowest SOR value in winter.

543 The NOR values in UNNC, LRABS and HMB shared a simlar seasonal pattern: Winter > 544 Spring $>$ Autumn $>$ Summer. The NOR values in highly-polluted winter and less polluted 545 summer are consistent with those reported in Shanghai, where the NOR during hazy days and 546 clean days were 0.18 and 0.08 , respectively (Hua et al., 2015). As discussed, the seasonal 547 variation of nitrate has shown an inverse relationship with the seasonal mean air temperature 548 variations. Low temperature $\left(<15^{\circ} \mathrm{C}\right)$ could favor the transformation of gaseous $\mathrm{NO}_{2}$ to 
particulate $\mathrm{NO}_{3}{ }^{-}$(Squizzato et al., 2012; US EPA, 1999). NOR in winter at these sampling sites have shown the highest value $(>0.1)$, which implies the greatest oxidation degree of $\mathrm{NO}_{2}$ to $\mathrm{NO}_{3}{ }^{-}$occured in the coldest season.. This is opposite to SOR trend, which shows the highest during summer. As mentioned earlier, high RH can increase the possibility of heterogeneous aqueous reaction of $\mathrm{SO}_{2}$ and $\mathrm{NO}_{2}$ to generate sulfate and gas-phase $\mathrm{HONO}$, while less $\mathrm{NO}_{2}$ might be converted into gas-phase $\mathrm{HONO}$ and more converted to particulate nitrate during the dry winter. Also, lowest NOR in summer could be the result of the highest temperature in this season favorable for the volatilization of nitrate when temperature $>30^{\circ} \mathrm{C}$ (Deng et al., 2015). The NOR pattern in NMB showed slightly different from the other sites: Autumn $(0.12)>$ Winter $(0.10)>$ Spring $(0.07)>$ Summer $(0.04)$. The highest NOR in autumn here might be attibuted to the greater increase of $\mathrm{NO}_{3}{ }^{-}$concentration $\left(10.28 \mu \mathrm{g} \mathrm{m}^{-3}\right.$, in Table 3$)$.

\subsubsection{Principal component analysis}

In order to investigate the possible sources of these ionic species in NZP, principal component analysis (PCA, SPSS version 19.0, IBM Corp.) has been applied in this work and the result is presented in Table 4. During the analysis, Varimax rotation was chosen to give a clearer pattern of variables loading in factors, and this feature can make the loadings of obvious variables close to 1 and non-obvious variables close to 0 (Meng et al., 2016). However, only those loadings $>0.3$ are shown in Table 4 , and those variables with loading $>0.5$ are considered to be the indicators of the factors (Callén et al., 2009).

Nine ions $\left(\mathrm{Na}^{+}, \mathrm{NH}_{4}^{+}, \mathrm{K}^{+}, \mathrm{Mg}^{2+}, \mathrm{Ca}^{2+}, \mathrm{Cl}^{-}, \mathrm{NO}_{2}^{-}, \mathrm{NO}_{3}^{-}, \mathrm{SO}_{4}{ }^{2-}\right)$ in NZP were selected for PCA analysis. $\mathrm{Li}^{+}, \mathrm{F}^{-}$and $\mathrm{PO}_{4}{ }^{3-}$ were undetectable in most of the aerosol samples due to their low presence level in the atmosphere; therefore, they were not included in PCA analysis. 
In winter, the variables resulted in 3 sources of eigenvalue $>1$ and they explained $72.9 \%$ of

572 variance in total. Factor 1 (Component 1 ) covered $42.8 \%$ of total variance, and is heavily loaded

573 with $\mathrm{NH}_{4}{ }^{+}, \mathrm{K}^{+}, \mathrm{Cl}^{-}, \mathrm{NO}_{3}{ }^{-}, \mathrm{SO}_{4}{ }^{2-}$, suggesting the contributions from secondary inorganic aerosols,

574 coal combustion and biomass burning. Factor 2, explaining 17.1\% of the data variance, is loaded

575 with $\mathrm{Na}^{+}, \mathrm{Ca}^{2+}$ and $\mathrm{Cl}^{-}$, possibly indicating their marine and dust sources, along with coal

576 combustion as well as factor 1 . Factor 3 is responsible for $13.0 \%$ of the variance, mainly affected

577 by $\mathrm{Mg}^{2+}$ and $\mathrm{NO}_{2}^{-}$. Since $\mathrm{NO}_{2}$ on wet crustal particle surface can form $\mathrm{NO}_{2}^{-}$through

578 heterogeneous reaction (Wang et al., 2015b) and crustal originated $\mathrm{Mg}^{2+}(\mathrm{r}=0.80)$ and $\mathrm{Ca}^{2+}(\mathrm{r}=$

579 0.88) were also found correlated well with $\mathrm{NO}_{2}^{-}$during winter at UNNC, therefore, $\mathrm{Mg}^{2+}$ and

$580 \mathrm{NO}_{2}^{-}$loaded factor 3 could be the result of heterogeneous conversion of $\mathrm{NO}_{2}$.

581 In spring, 2 factors were obtained from PCA model. Factor 1, explaining 37.6\% of variables, 582 is loaded with $\mathrm{Na}^{+}, \mathrm{NH}_{4}^{+}, \mathrm{K}^{+}, \mathrm{NO}_{3}{ }^{-}$and $\mathrm{SO}_{4}{ }^{2-}$, indicating likely sources from sea salts, biomass

583 burning and secondary aerosols. Factor 2 explains $18.6 \%$ of the variables, is affected by $\mathrm{Mg}^{2+}$, $584 \mathrm{Ca}^{2+}$ and $\mathrm{Cl}^{-}$, suggesting the contributions of suspending dust and coal combustion to the fine 585 particles in the atmosphere.

586 The PCA results in summer also have 2 factors, similar with those in spring. Factor 1, 587 accounting for $38.6 \%$ of the variables, is loaded with $\mathrm{NH}_{4}^{+}, \mathrm{K}^{+}, \mathrm{Cl}^{-}, \mathrm{NO}_{3}^{-}, \mathrm{SO}_{4}{ }^{2-}$, suggesting 588 contributions from industrial emissions, biomass burning and coal burning. Factor 2 explains $58920.0 \%$ of the variance with loading of $\mathrm{Na}^{+}, \mathrm{Mg}^{2+}$ and $\mathrm{Ca}^{2+}$, which are likely from sea salts and 590 dust particles. This is consistent with the cluster results in Fig. 2 that most of the air masses were 591 originated from the ocean, passed through mainland to reach studied sites and 10-29\% was from 592 central China. Therefore, the aerosols were characterized with both oceanic and terrestrial 593 properties. 
In autumn, 3 PCA factors were calculated, explaining $75.0 \%$ of the total variance. Factor 1 explained $44.5 \%$ of the variance, dominated by $\mathrm{NH}_{4}{ }^{+}, \mathrm{K}^{+}, \mathrm{NO}_{3}{ }^{-}$and $\mathrm{SO}_{4}{ }^{2-}$ with obvious loading 596 above 0.8 , and $\mathrm{K}^{+}$is found to correlate very well with $\mathrm{PM}_{2.5}, \mathrm{NO}_{3}{ }^{-}$and $\mathrm{NH}_{4}{ }^{+}$at this region $(\mathrm{r}>$ 597 0.80), strongly suggesting emissions from industrial areas and biomass burning. Factor 2, 598 responsible for $16.2 \%$ of the total variance, is loaded with $\mathrm{Na}^{+}, \mathrm{Mg}^{2+}, \mathrm{Ca}^{2+}$ and $\mathrm{Cl}^{-}$, indicating 599 sources like sea salt, dust particles and coal burning. Only $\mathrm{NO}_{2}^{-}$in Factor 3 has loading above 0.5 , 600 indicating the origin from vehicle exhaust.

601

602

603

604

605

606

607

608

609

610

611

612

613

614

615

\section{Conclusions}

The seasonal variations of ion chemistry and sources of WSII were studied through a oneyear sampling campaign at 4 representative sites in both Hangzhou and Ningbo of NZP. The annual averaged $\mathrm{PM}_{2.5}$ and total WSII concentrations in NZP were $66.2 \pm 37.7 \mu \mathrm{g} \mathrm{m}^{-3}$ and $29.1 \pm$ $19.9 \mu \mathrm{g} \mathrm{m}^{-3}$, respectively. WSII in this region were dominated by $\mathrm{SO}_{4}{ }^{2-}, \mathrm{NO}_{3}{ }^{-}, \mathrm{NH}_{4}{ }^{+}, \mathrm{Cl}^{-}$and $\mathrm{K}^{+}$. SNA ranked as the top three ions, accounting for $88.0 \%$ of total WSII and $38.7 \%$ of $\mathrm{PM}_{2.5}$ occurrence levels. The seasonal average WSII exhibited the highest in winter and lowest in summer and spatially the annual total WSII at sites in Ningbo were relatively lower than those in Hangzhou, indicating the aerosol ionic pollution was more severe within the provincial capital municipality.

Aerosol acidity was also studied through ion balance. At UNNC and $\mathrm{HMB}, \mathrm{NO}_{3}{ }^{-}$and $\mathrm{SO}_{4}{ }^{2-}$ were mostly neutralized by $\mathrm{Ca}^{2+}$ and $\mathrm{NH}_{4}{ }^{+}$. In winter and spring at LRABS, the alkaline nature of aerosols could be possibly due to the increased biomass burning emission and volatilization of ammonia containing fertilizer; but the alkaline nature of aerosol in NMB could be the result of enhanced traffic emitted $\mathrm{NH}_{3}$. Among all cations, $\mathrm{NH}_{4}{ }^{+}$was the predominant neutralizing ion 
616 with the highest neutralization factor (NF); while the NFs of nss-Ca ${ }^{2+}, \mathrm{nss}^{-} \mathrm{K}^{+}$and $\mathrm{Mg}^{2+}$ were

617 lower than 0.2 , implying minor impact of these ions in the neutralization of aerosol acidity.

618 High ratios of nss-SO ${ }^{2-} / \mathrm{SO}_{4}{ }^{2-}, \mathrm{nss}^{-} \mathrm{K}^{+} / \mathrm{K}^{+}$and $\mathrm{nss}-\mathrm{Ca}^{2+} / \mathrm{Ca}^{2+}$ at all four sites of NZP indicated

619 minor marine contribution to these ions. High correlations of $\mathrm{NH}_{4}^{+}$with $\mathrm{NO}_{3}^{-}$and $\mathrm{SO}_{4}{ }^{2-}(\mathrm{r}$ :

$620 \quad 0.8 \sim 1.0$ ) were observed throughout the sampling period at 4 sites and the annual averaged molar

621 ratio of $\left[\mathrm{NH}_{4}^{+}\right] /\left[\mathrm{SO}_{4}{ }^{2-}\right]$ of 4 sites were all above 3.3 , indicating $\mathrm{NH}_{4}{ }^{+}$existed predominantly as

622 ammonium sulfates, ammonium bi-sulfates and ammonium nitrates in aerosols. The SOR value

623 in all seasons of NZP were above 0.1 , indicating $\mathrm{SO}_{2}-\mathrm{SO}_{4}{ }^{2-}$ transformation dominantly

624 occurred throughout the year in NZP, and it was the highest in summer and lowest in winter;

625 however, the NOR seasonal pattern was the opposite to that of SOR. The seasonal values of SOR

626 and NOR seem to be significantly affected by both homogeneous and heterogeneous reactions

627 for the gaseous precursors converted to secondary ions and volatilization of nitrates under high

628 ambient temperature.

629 The sources of WSII were also investigated by PCA and the results showed that they were 630 predominantly from industrial emissions, biomass burning, secondary inorganic aerosols, 631 moderately from dust and soil originated particles and minorly from sea salts. In addition, the air 632 mass backward trajectory analysis also showed that the contribution from transboundary 633 transport of aerosols from highly polluted north China may not be negligible.

\section{Acknowledgement} authors acknowledge the financial support from the International Doctoral Innovation Centre,

637 Ningbo Education Bureau, Ningbo Science and Technology Bureau, China's MOST and The 638 University of Nottingham. This work is also partially supported by Natural Science Foundation 
639 of China (41303091, 41405116, 41675124 \& 91544229), EPSRC grant EP/L016362/1, Zhejiang

640 Provincial Applied Research Program for Commonweal Technology (2015C33011), Strategic

641 Priority Research Program (B) of the Chinese Academy of Sciences (XDB05020403), and Open

642 Funds from Jiangsu Key Laboratory of AEMPC (KHK1304 \& KHK1204).

643 Conflict of interests

644 The authors declare no conflict of interests at personal and/or organizational level. 


\section{Reference}

Baek, B.H., Aneja, V.P., Tong, Q., 2004. Chemical coupling between ammonia, acid gases, and fine particles. Environ. Pollut. 129, 89-98.

Balasubramanian, R., Qian, W.B., Decesari, S., Facchini, M.C., Fuzzi, S., 2003. Comprehensive characterization of $\mathrm{PM}_{2.5}$ aerosols in Singapore. J. Geophys. Res-Atmos. 108.

Behera, S.N., Cheng, J., Huang, X., Zhu, Q., Liu, P., Balasubramanian, R., 2015. Chemical composition and acidity of size-fractionated inorganic aerosols of 2013-14 winter haze in Shanghai and associated health risk of toxic elements. Atmos. Environ. 122, 259-271.

Callén, M.S., de la Cruz, M.T., López, J.M., Navarro, M.V., Mastral, A.M., 2009. Comparison of receptor models for source apportionment of the PM10 in Zaragoza (Spain). Chemosphere $76,1120-1129$.

Chen, J., Li, C., Ristovski, Z., Milic, A., Gu, Y., Islam, M.S., Wan,g S., Hao, J., Zhang, H., He, C., Guo, H., Fu, H., Miljevic, B., Morawska, L., Thai, P., Lam, Y.F., Pereira, G., Ding, A., Huang, X., Dumka, U.C., 2016. A review of biomass burning: Emissions and impacts on air quality, health and climate in China. Sci. Total Environ.

Chow, J.C., Watson, J.G., Kuhns, H., Etyemezian, V., Lowenthal, D.H., Crow, D., Kohl, S.D., Engelbrecht, J.P., Green, M.C., 2004. Source profiles for industrial, mobile, and area sources in the Big Bend Regional Aerosol Visibility and Observational study. Chemosphere $54,185-208$.

Deng, X.L., Shi, C.E., Wu, B.-w., Yang, Y.J., Jin, Q., Wang, H.L., Zhu S., Yu C., 2016. Characteristics of the water-soluble components of aerosol particles in Hefei, China. J. Environ. Sci. 42, 32-40.

Draxler, R.R.R., G.D., 2013. HYSPLIT (HYbrid Single-Particle Lagrangian Integrated Trajectory) Model access via NOAA ARL READY Website (http://ready.arl.noaa.gov/HYSPLIT.php). NOAA Air Resources Laboratory, Silver Spring, MD.

Fang, G.C., Lin, S.C., Chang, S.Y., Lin, C.Y., Chou, C.C.K., Wu, Y.J., Chen, Y.C., Chen, W.T., $\mathrm{Wu}$, T.L., 2011. Characteristics of major secondary ions in typical polluted atmospheric aerosols during autumn in central Taiwan. J. Environ. Manage. 92, 1520-1527.

Gao, X., Yang, L., Cheng, S., Gao, R., Zhou, Y., Xue, L., Shou, Y., Wang, J., Wang, X., Nie, W., Xu, P., Wang, W., 2011. Semi-continuous measurement of water-soluble ions in $\mathrm{PM}_{2.5}$ 
in Jinan, China: Temporal variations and source apportionments. Atmos. Environ. 45, 60486056.

Haas, J., Ban, Y.F., 2014. Urban growth and environmental impacts in Jing-Jin-Ji, the Yangtze, River Delta and the Pearl River Delta. Int. J. Appl. Earth Obs. Geoinf. 30, 42-55.

Han, B., Zhang, R., Yang, W., Bai, Z., Ma, Z., Zhang, W., 2016. Heavy haze episodes in Beijing during January 2013: Inorganic ion chemistry and source analysis using highly timeresolved measurements from an urban site. Sci. Total Environ. 544, 319-329.

He, J., Balasubramanian, R., 2008. Rain-aerosol coupling in the tropical atmosphere of Southeast Asia: distribution and scavenging ratios of major ionic species. J. Atmos. Chem. 60, 205-220.

He, J., Balasubramanian, R., Burger, D., Hicks, K., Kuylenstierna, J.C.I., Palani, S., 2011. Dry and wet atmospheric deposition of nitrogen and phosphorus in Singapore. Atmos. Environ. 45, 2760-2768.

He, K.B., Yang, F.M., Ma, Y.L., Zhang, Q., Yao, X.H., Chan, C.K., Cadle, S., Chan, T., Mulawa, P., 2001. The characteristics of $\mathrm{PM}_{2.5}$ in Beijing, China. Atmos. Environ. 35, 49594970.

Hu, G., Zhang, Y., Sun, J., Zhang, L., Shen, X., Lin, W., Yang, Y., 2014. Variability, formation and acidity of water-soluble ions in $\mathrm{PM}_{2.5}$ in Beijing based on the semi-continuous observations. Atmos. Res. 145-146, 1-11.

Hu, M., Wu, Z., Slanina, J., Lin, P., Liu, S., Zeng, L., 2008. Acidic gases, ammonia and watersoluble ions in $\mathrm{PM}_{2.5}$ at a coastal site in the Pearl River Delta, China. Atmos. Environ. 42, 6310-6320.

Hua, W., Chen, Z.M., Jie, C.Y., Kondo, Y., Hofzumahaus, A., Takegawa, N., Chang, C.C., Lu, K.D., Miyazaki, Y., Kita, K., Wang, H.L., Zhang, Y.H., Hu, M., 2008. Atmospheric hydrogen peroxide and organic hydroperoxides during PRIDE-PRD'06, China: their concentration, formation mechanism and contribution to secondary aerosols. Atmos. Chem. Phys. 8, 6755-6773.

Hua, Y., Cheng, Z., Wang, S., Jiang, J., Chen, D., Cai, S., Fu, X., Fu, Q., Chen, C., Xu, B., Yu, J., 2015. Characteristics and source apportionment of $\mathrm{PM}_{2.5}$ during a fall heavy haze episode in the Yangtze River Delta of China. Atmos. Environ. 123, Part B, 380-391. 
Huang, X., Liu, Z., Zhang, J., Wen, T., Ji, D., Wang, Y., 2016. Seasonal variation and secondary formation of size-segregated aerosol water-soluble inorganic ions during pollution episodes in Beijing. Atmos. Res. 168, 70-79.

Kang, C.M., Lee, H.S., Kang, B.W., Lee, S.K., Sunwoo, Y., 2004. Chemical characteristics of acidic gas pollutants and $\mathrm{PM}_{2.5}$ species during hazy episodes in Seoul, South Korea. Atmos. Environ. 38, 4749-4760.

Kang, J., Cho, B.C., Lee, C.B., 2010. Atmospheric transport of water-soluble ions $\left(\mathrm{NO}_{3}{ }^{-}, \mathrm{NH}_{4}{ }^{+}\right.$ and nss-SO ${ }_{4}^{2-}$ ) to the southern East Sea (Sea of Japan). Sci. Total Environ. 408, 2369-2377.

Kong, S., Wen, B., Chen, K., Yin, Y., Li, L., Li, Q., Yuan, L., Li, X., Sun, X., 2014. Ion chemistry for atmospheric size-segregated aerosol and depositions at an offshore site of Yangtze River Delta region, China. Atmos. Res. 147-148, 205-226.

Li, B., Zhang, J., Zhao, Y., Yuan, S., Zhao, Q., Shen, G., Wu H., 2015. Seasonal variation of urban carbonaceous aerosols in a typical city Nanjing in Yangtze River Delta, China. Atmos. Environ. 106, 223-231.

Li, J.W., Han, Z.W., 2016. Seasonal Variation of Nitrate Concentration and Its Direct Radiative Forcing over East Asia. Atmosphere 7.

Lin, C.C., Huang, K.L., Chen, S.J., Liu, S.C., Tsai, J.H., Lin, Y.C., Lin, W.Y., 2009. $\mathrm{NH}_{4}^{+}$, $\mathrm{NO}_{3}{ }^{-}$, and $\mathrm{SO}_{4}{ }^{2-}$ in roadside and rural size-resolved particles and transformation of $\mathrm{NO} 2 / \mathrm{SO} 2$ to nanoparticle-bound $\mathrm{NO}_{3}{ }^{-} / \mathrm{SO}_{4}{ }^{2-}$. Atmos. Environ. 43, 2731-2736.

Lin, J.J., 2002. Characterization of water-soluble ion species in urban ambient particles. Environ. Int. 28, 55-61.

Liu, Z.R., Hu, B., Zhang, J.K., Yu, Y.C., Wang, Y.S., 2016. Characteristics of aerosol size distributions and chemical compositions during wintertime pollution episodes in Beijing. Atmos. Res. 168, 1-12.

Meng, C.C., Wang, L.T., Zhang, F.F., Wei, Z., Ma, S.M., Ma, X., Yang, J., 2016. Characteristics of concentrations and water-soluble inorganic ions in $\mathrm{PM}_{2.5}$ in Handan City, Hebei province, China. Atmos. Res. 171, 133-146.

MEP, 2012. China National Ambient Air Quality Standards, Ministry of Environmental Protection, Beijing, China. 
Niu, X., Cao, J., Shen, Z., Ho, S.S.H., Tie, X., Zhao, S., Xu, H., Zhang, T., Huang, R., 2016. $\mathrm{PM}_{2.5}$ from the Guanzhong Plain: Chemical composition and implications for emission reductions. Atmos. Environ. 147, 458-469.

Ohta, S., Okita, T., 1990. A chemical characterization of atmospheric aerosol in Sapporo. Atmos. Environ. Part A. General Topics. 24, 815-822.

Pan, Y.P., Tian, S.L., Liu, D.W., Fang, Y.T., Zhu, X.Y., Zhang, Q., Zheng, B., Michalski, G., Wang, Y.S., 2016. Fossil Fuel Combustion-Related Emissions Dominate Atmospheric Ammonia Sources during Severe Haze Episodes: Evidence from N-15-Stable Isotope in Size-Resolved Aerosol Ammonium. Environ. Sci. Technol. 50, 8049-8056.

Pathak, R.K., Wu, W.S., Wang, T., 2009. Summertime $\mathrm{PM}_{2.5}$ ionic species in four major cities of China: nitrate formation in an ammonia-deficient atmosphere. Atmos. Chem. Phys. 9, 1711-1722.

Pei, B., Wang, X., Zhang, Y., Hu, M., Sun, Y., Deng, J., Dong, L., Fu, Q., Yan, N., 2016. Emissions and source profiles of $\mathrm{PM}_{2.5}$ for coal-fired boilers in the Shanghai megacity, China. Atmos. Pollut. Res. 7, 577-584.

Pope, C.A., Dockery, D.W., 2006. Health effects of fine particulate air pollution: Lines that connect. J. Air Waste Manage. Assoc. 56, 709-742.

Pope, C.A., III Burnett, R.T., Thun, M.J., Calle, E.E., Krewski, D., Ito, K., Thurston, G.D., 2002. Lung cancer, cardiopulmonary mortality, and long-term exposure to fine particulate air pollution. J. Am. Med. Assoc. (JAMA) 287, 1132-1141.

Qiao, T., Zhao, M., Xiu, G., Yu, J., 2015. Seasonal variations of water soluble composition (WSOC, Hulis and WSIIs) in $\mathrm{PM}_{1}$ and its implications on haze pollution in urban Shanghai, China. Atmos. Environ. 123, Part B, 306-314.

Ran, L., Deng, Z.Z., Wang, P.C., Xia, X.A., 2016. Black carbon and wavelength-dependent aerosol absorption in the North China Plain based on two-year aethalometer measurements. Atmos. Environ. 142, 132-144.

Rolph, G.D., 2013. Real-time Environmental Applications and Display sYstem (READY) Website (http://ready.arl.noaa.gov) NOAA Air Resources Laboratory, Silver Spring, MD.

Safai, P.D., Budhavant, K.B., Rao, P.S.P., Ali, K., Sinha, A., 2010. Source characterization for aerosol constituents and changing roles of calcium and ammonium aerosols in the neutralization of aerosol acidity at a semi-urban site in SW India. Atmos. Res. 98, 78-88. 
Satsangi, A., Pachauri, T., Singla, V., Lakhani, A., Kumari, K.M., 2013. Water Soluble Ionic Species in Atmospheric Aerosols: Concentrations and Sources at Agra in the Indo-Gangetic Plain (IGP). Aerosol Air Qual. Res. 13, 1877-1889.

Seidel, D.J., Ao, C.O., Li, K., 2010. Estimating climatological planetary boundary layer heights from radiosonde observations: Comparison of methods and uncertainty analysis. J. Geophys. Res-Atmos. 115.

Sheng, L., Tang, X., You, H., Gu, Q., Hu, H., 2017. Comparison of the urban heat island intensity quantified by using air temperature and Landsat land surface temperature in Hangzhou, China. Ecol. Indic. 72, 738-746.

Squizzato, S., Masiol, M., Innocente, E., Pecorari, E., Rampazzo, G., Pavoni, B., 2012. A procedure to assess local and long-range transport contributions to $\mathrm{PM}_{2.5}$ and secondary inorganic aerosol. J. Aerosol Sci. 46, 64-76.

Tao, J., Ho, K.F., Chen, L., Zhu, L., Han, J., Xu, Z., 2009. Effect of chemical composition of $\mathrm{PM}_{2.5}$ on visibility in Guangzhou, China, 2007 spring. Particuology 7, 68-75.

Tian, S., Pan, Y., Liu, Z., Wen, T., Wang, Y., 2014. Size-resolved aerosol chemical analysis of extreme haze pollution events during early 2013 in urban Beijing, China. J. Hazard. Mater. $279,452-460$.

Toledano, C., Cachorro, V.E., Gausa, M., Stebel, K., Aaltonen, V., Berjón, A., Ortiz de Galisteo, J.P., de Frutos, A.M., Bennouna, Y., Blindheim, S., Myhre, C.L., Zibordi, G., Wehrli, C., Kratzer, S., Hakansson, B., Carlund, T., de Leeuw, G., Herber, A., Torres, B., 2012. Overview of sun photometer measurements of aerosol properties in Scandinavia and Svalbard. Atmos. Environ. 52, 18-28.

Tsai, Y.I., Chen, C.L., 2006. Atmospheric aerosol composition and source apportionments to aerosol in southern Taiwan. Atmos. Environ. 40, 4751-4763.

Ueda, S., Hirose, Y., Miura, K., Okochi, H., 2014. Individual aerosol particles in and below clouds along a Mt. Fuji slope: Modification of sea-salt-containing particles by in-cloud processing. Atmos. Res. 137, 216-227.

US EPA, 1999. Particulate matter (PM2.5) speciation guidance document (Third draft). 69.

Waldman, J.M., Lioy, P.J., Zelenka, M., Jing, L., Lin, Y.N., He, Q.C., Qian, Z.M., Chapman, R., Wilson, W.E., 1991. Wintertime measurements of aerosol acidity and trace elements in Wuhan, a city in central China. Atmos. Environ. Part B. Urban Atmosphere 25, 113-120. 
Wang, G., Zhang, R., Gomez, M.E., Yang, L., Levy, Zamora, M., Hu, M., Lin, Y., Peng, J., Guo, S., Meng, J., Li, J., Cheng, C., Hu, T., Ren, Y., Wang, Y., Gao, J., Cao, J., An, Z., Zhou, W., Li, G., Wang, J., Tian, P., Marrero-Ortiz, W., Secrest, J., Du, Z., Zheng, J., Shang, D., Zeng, L., Shao, M., Wang, W., Huang, Y., Wang, Y., Zhu, Y., Li, Y., Hu, J., Pan, B., Cai, L., Cheng, Y., Ji, Y., Zhang, F., Rosenfeld, D., Liss, P.S., Duce, R.A., Kolb, C.E., Molina, M.J., 2016a. Persistent sulfate formation from London Fog to Chinese haze. Proc. Natl. Acad. Sci. U. S. A. 113, 13630-13635.

Wang, H., An, J., Cheng, M., Shen, L., Zhu, B., Li, Y., Wang, Y., Duan, Q., Sullivan, A., Xia, L., 2016b. One year online measurements of water-soluble ions at the industrially polluted town of Nanjing, China: Sources, seasonal and diurnal variations. Chemosphere 148, 526536.

Wang, H., Zhu, B., Shen, L., Xu, H., An, J., Xue, G., Cao, J., 2015a. Water-soluble ions in atmospheric aerosols measured in five sites in the Yangtze River Delta, China: Sizefractionated, seasonal variations and sources. Atmos. Environ. 123, Part B, 370-379.

Wang, H.L., Qiao, L.P., Lou, S.R., Zhou, M., Ding, A.J., Huang, H.Y., Chen, J.M., Wang, Q., Tao, S.K., Chen, C.H., Li, L., Huang, C., 2016c. Chemical composition of $\mathrm{PM}_{2.5}$ and meteorological impact among three years in urban Shanghai, China. J. Clean. Prod. 112, Part 2, 1302-1311.

Wang, L.W., Wen, L., Xu, C.H., Chen, J.M., Wang, X.F., Yang, L.X., Wang, W.X., Yang, X., Sui, X., Yao, L., Zhang, Q.Z., 2015b. HONO and its potential source particulate nitrite at an urban site in North China during the cold season. Sci. Total Environ. 538, 93-101.

Wang, Y., Ying, Q., Hu, J., Zhang, H., 2014. Spatial and temporal variations of six criteria air pollutants in 31 provincial capital cities in China during 2013-2014. Environ. Int. 73, 413422.

Wang, Y., Zhuang, G., Zhang, X., Huang, K., Xu, C., Tang, A., Chen, J., An, Z., 2006. The ion chemistry, seasonal cycle, and sources of PM2.5 and TSP aerosol in Shanghai. Atmos. Environ. 40, 2935-2952.

Whitburn, S., Van Damme, M., Kaiser, J.W., van der Werf, G.R., Turquety, S., Hurtmans, D., Clarisse, L., Clerbaux, C., Coheur, P.F., 2015. Ammonia emissions in tropical biomass burning regions: Comparison between satellite-derived emissions and bottom-up fire inventories. Atmos. Environ. 121, 42-54. 
Xie, R., Seip, H.M., Wibetoe, G., Nori, S., McLeod, C.W., 2006. Heavy coal combustion as the dominant source of particulate pollution in Taiyuan, China, corroborated by high concentrations of arsenic and selenium in PM10. Sci. Total Environ. 370, 409-415.

Xu, H., Pu, J., He, J., Liu, J., Qi, B., Du, R., 2016a. Characteristics of atmospheric compositions in the background area of Yangtze River Delta during heavy air pollution episode. Adv. Meteorol. Article Number:7240486.

Xu, J.S., Xu, H.H., Xiao, H., Tong, L., Snape, C.E., Wang, C.J., He, J., 2016b. Aerosol composition and sources during high and low pollution periods in Ningbo, China. Atmos. Res. 178-179, 559-569.

Xu, J., Wang, Z., Yu, G., Qin, X., Ren, J., Qin, D., 2014. Characteristics of water soluble ionic species in fine particles from a high altitude site on the northern boundary of Tibetan Plateau: Mixture of mineral dust and anthropogenic aerosol. Atmos. Res. 143, 43-56.

Xue, Y., Zhou, Z., Nie, T., Wang, K., Nie, L., Pan, T., Wu, X., Tian, H., Zhong, L., Li, J., Liu, H., Liu, S., Shao, P., 2016. Trends of multiple air pollutants emissions from residential coal combustion in Beijing and its implication on improving air quality for control measures. Atmos. Environ. 142, 303-312.

Yin, S., Wang, X., Xiao, Y., Tani, H., Zhong, G., Sun, Z., 2017. Study on spatial distribution of crop residue burning and $\mathrm{PM}_{2.5}$ change in China. Environ. Pollut. 220, 204-221.

Zhang, R.Y., Leu, M.T., Keyser, L.F., 1995. Hydrolysis of $\mathrm{N}_{2} \mathrm{O}_{5} \mathrm{O}$ and $\mathrm{CLONO}_{2}$ on the $\mathrm{H} 2 \mathrm{SO} / \mathrm{HNO} / \mathrm{H} 2 \mathrm{O}$ ternary solutions under stratospheric conditions. Geophys. Res. Lett. 22, 1493-1496.

Zhang, T., Cao, J.J., Tie, X.X., Shen, Z.X., Liu, S.X., Ding, H., Han, Y.M., Wang, G.H., Ho, K.F., Qiang, J., Li, W.T., 2011. Water-soluble ions in atmospheric aerosols measured in Xi'an, China: Seasonal variations and sources. Atmos. Res. 102, 110-119.

Zhao, J., Zhang, F., Xu, Y., Che,n J., 2011. Characterization of water-soluble inorganic ions in size-segregated aerosols in coastal city, Xiamen. Atmos. Res. 99, 546-562.

Zhou, J., Xing, Z., Deng, J., Du, K., 2016. Characterizing and sourcing ambient PM2.5 over key emission regions in China I: Water-soluble ions and carbonaceous fractions. Atmos. Environ. 135, 20-30. 


\section{$857 \quad$ Figure captions}

858 Fig. 1 Locations of sampling sites in NZP, China (NCP: North China Plain; NWC: Northwest 859 China; PRD: Pearl River Delta; YRD: Yangtze River Delta)

860 Fig. 2 Clusters of air mass backward trajectories during each season in sampling sites of NZP

861 Fig. 3 Plot of anion equivalents (AE) vs cation equivalents (CE) in four seasons of NZP

862 Fig. 4 The neutralization factors of $\mathrm{nss}_{-} \mathrm{Ca}^{2+}, \mathrm{Mg}^{2+}, \mathrm{nss}^{-} \mathrm{K}^{+}$and $\mathrm{NH}_{4}{ }^{+}$in $\mathrm{PM}_{2.5}$ at 4 sites of NZP

863 Fig. 5 Concentration of non-sea salts and their respective non-sea salt ionic fractions at sampling 864 sites of NZP 

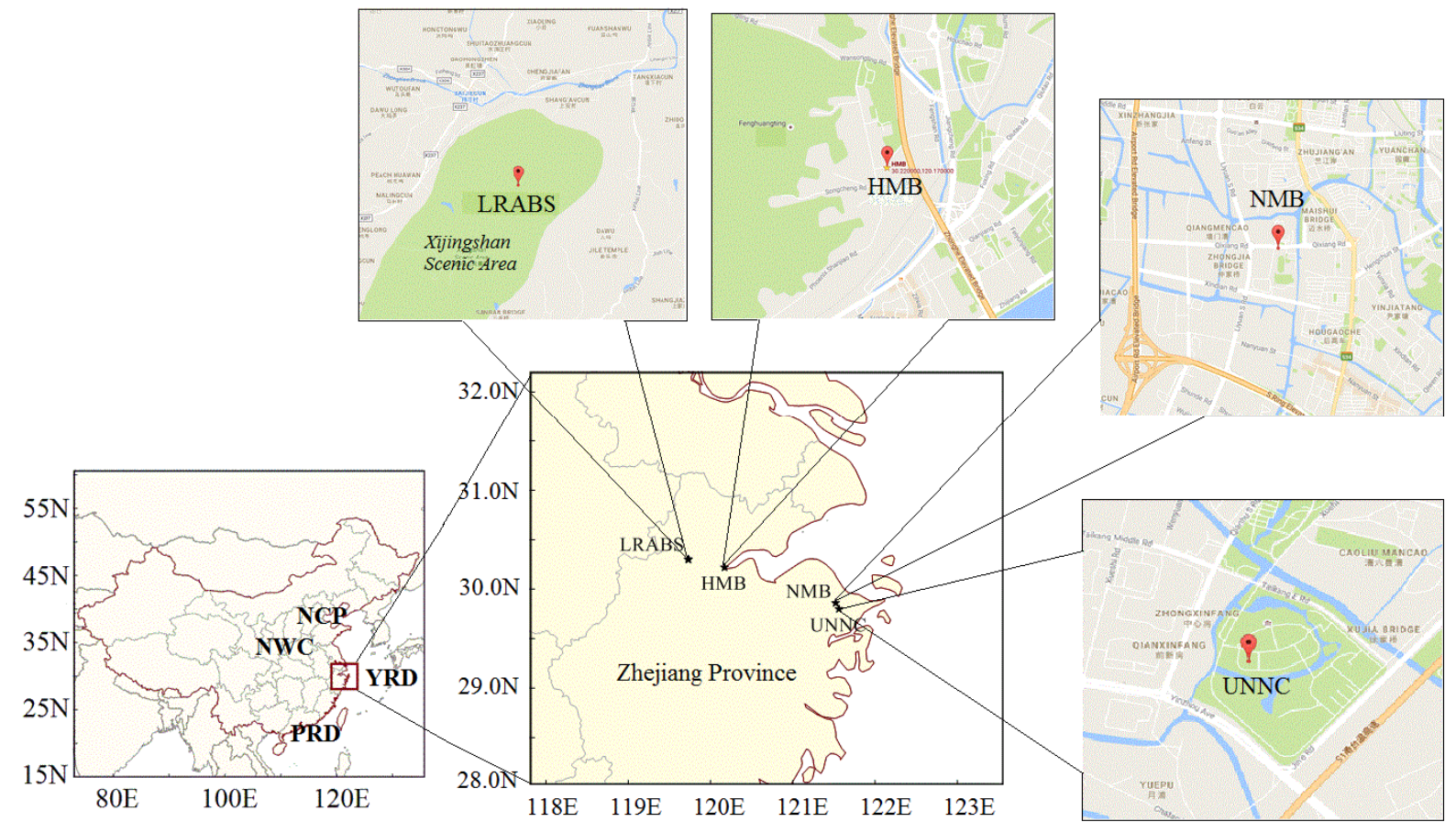

Fig. 1. Locations of sampling sites in NZP, China (NCP: North China Plain; NWC: Northwest China; PRD: Pearl River Delta; YRD: Yangtze River Delta) 


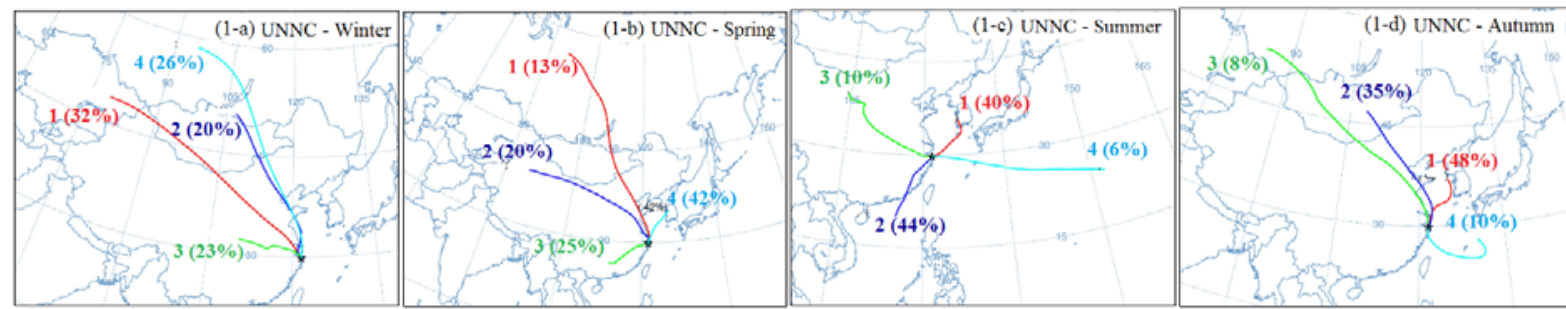

871

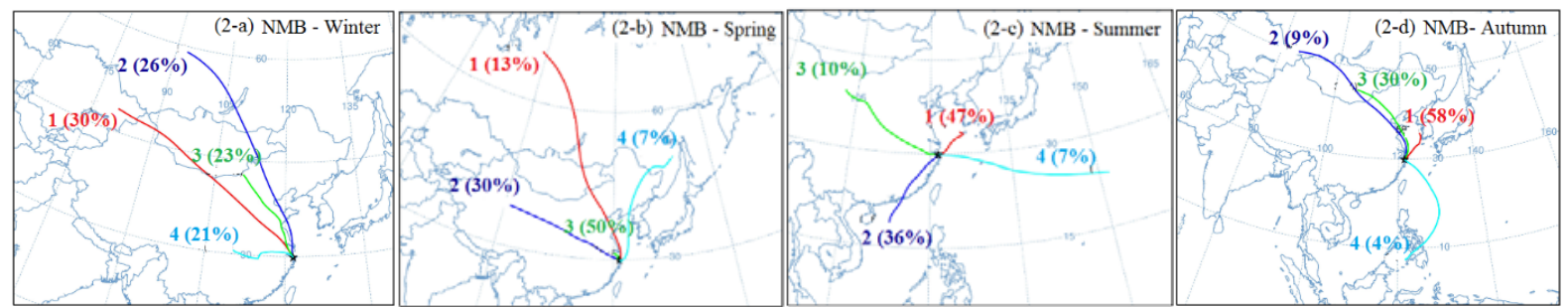

872
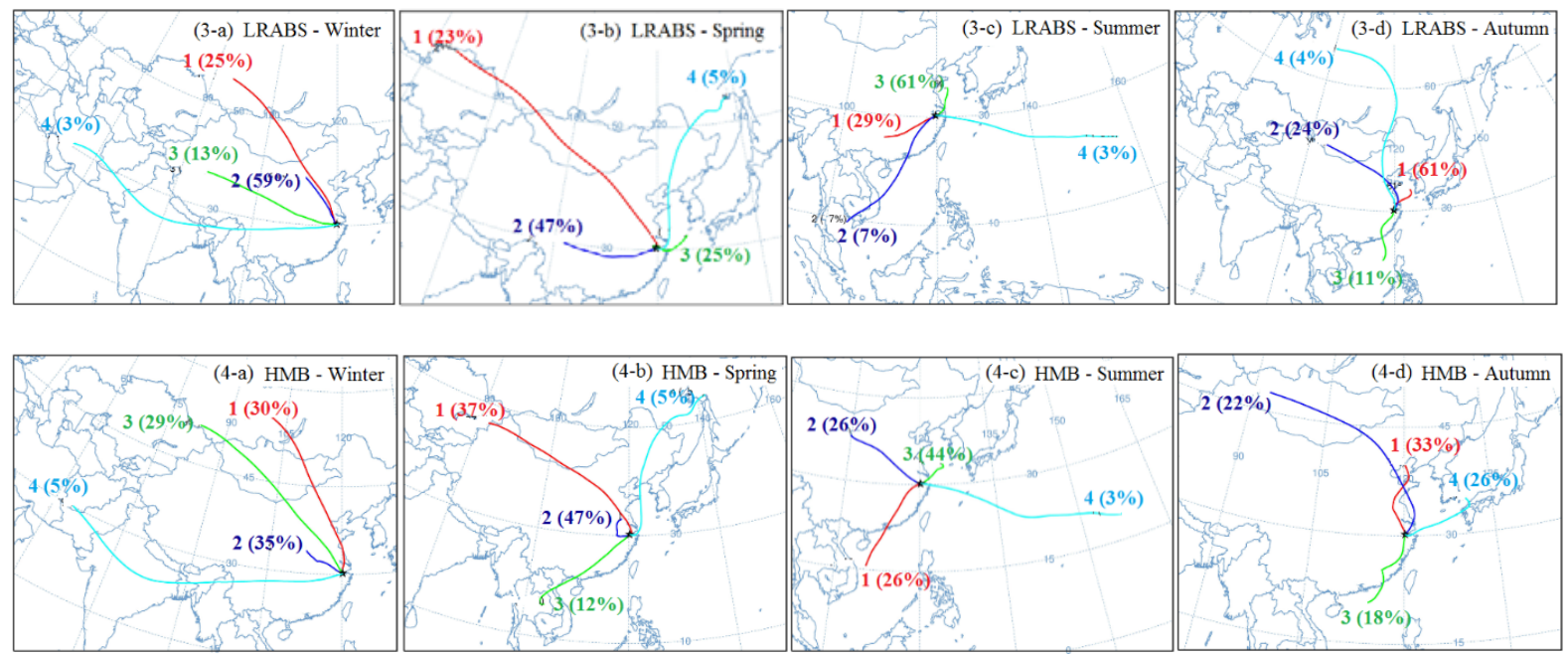

Fig. 2. Clusters of air mass backward trajectories during each season in sampling sites of NZP 

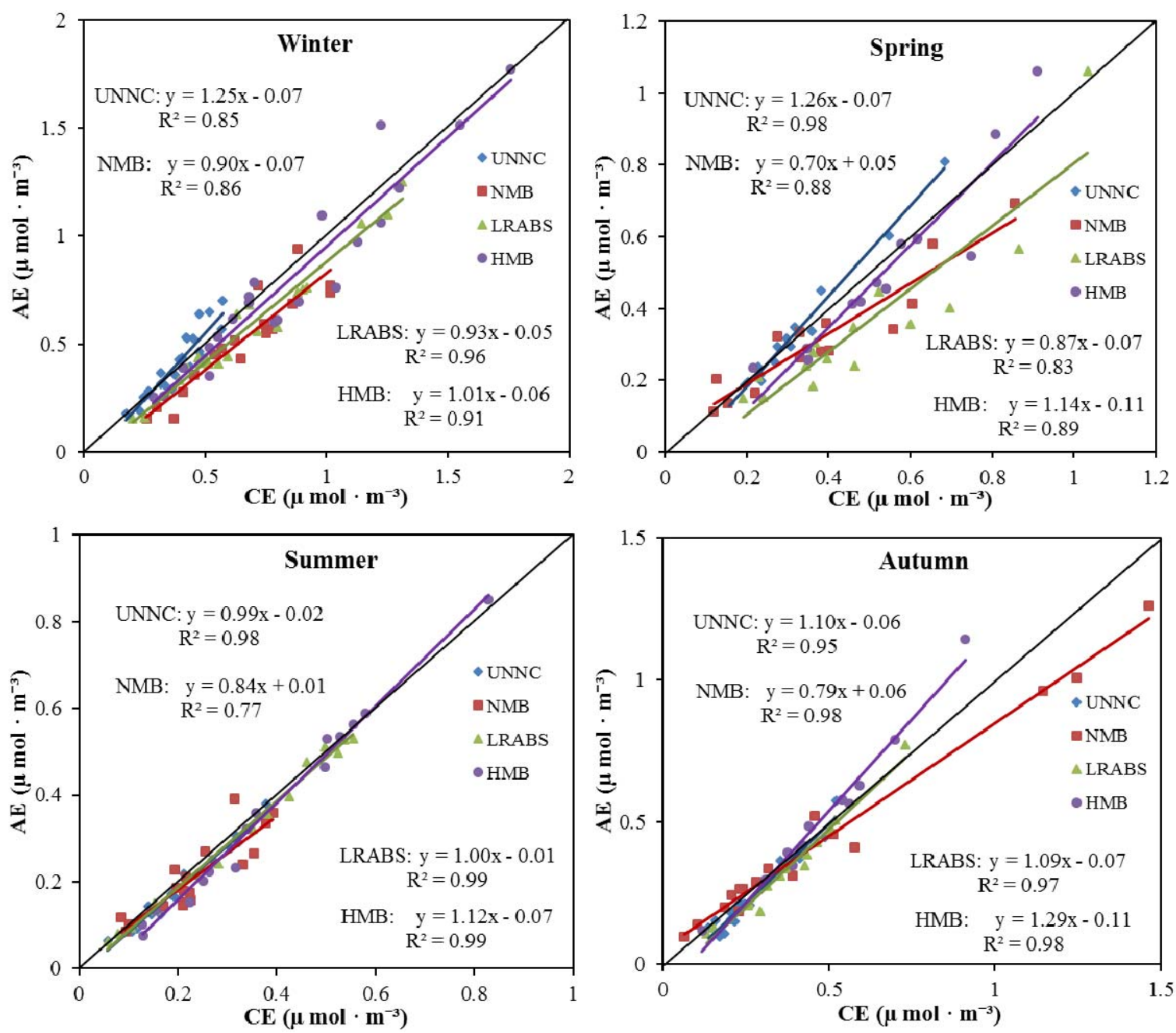

Fig. 3. Plot of anion equivalents (AE) vs cation equivalents (CE) in four seasons of NZP 


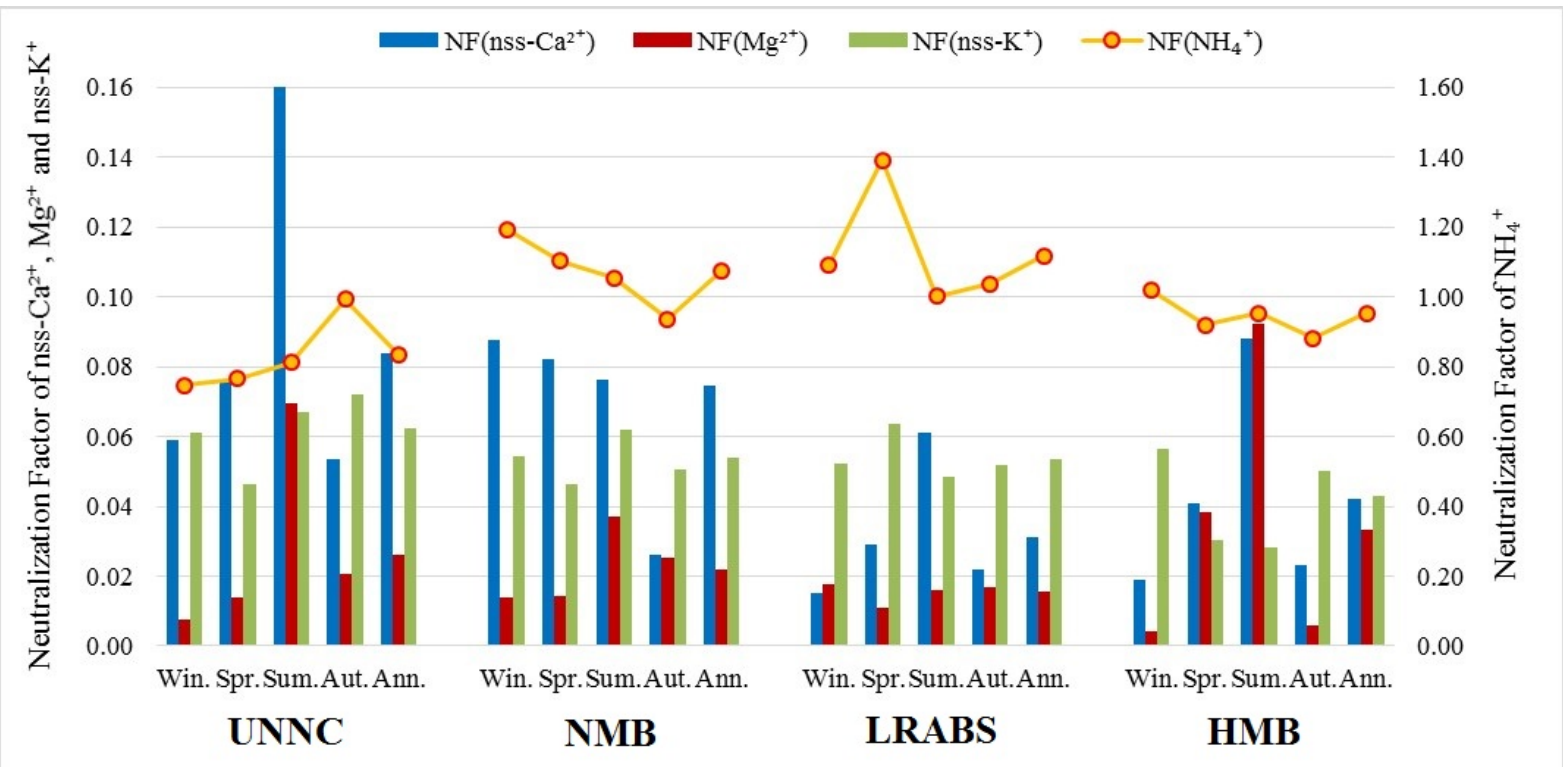

Fig. 4. The neutralization factors of nss- $-\mathrm{Ca}^{2+}, \mathrm{Mg}^{2+}$, nss- $\mathrm{K}^{+}$and $\mathrm{NH}_{4}{ }^{+}$in $\mathrm{PM}_{2.5}$ at 4 sites of NZP 


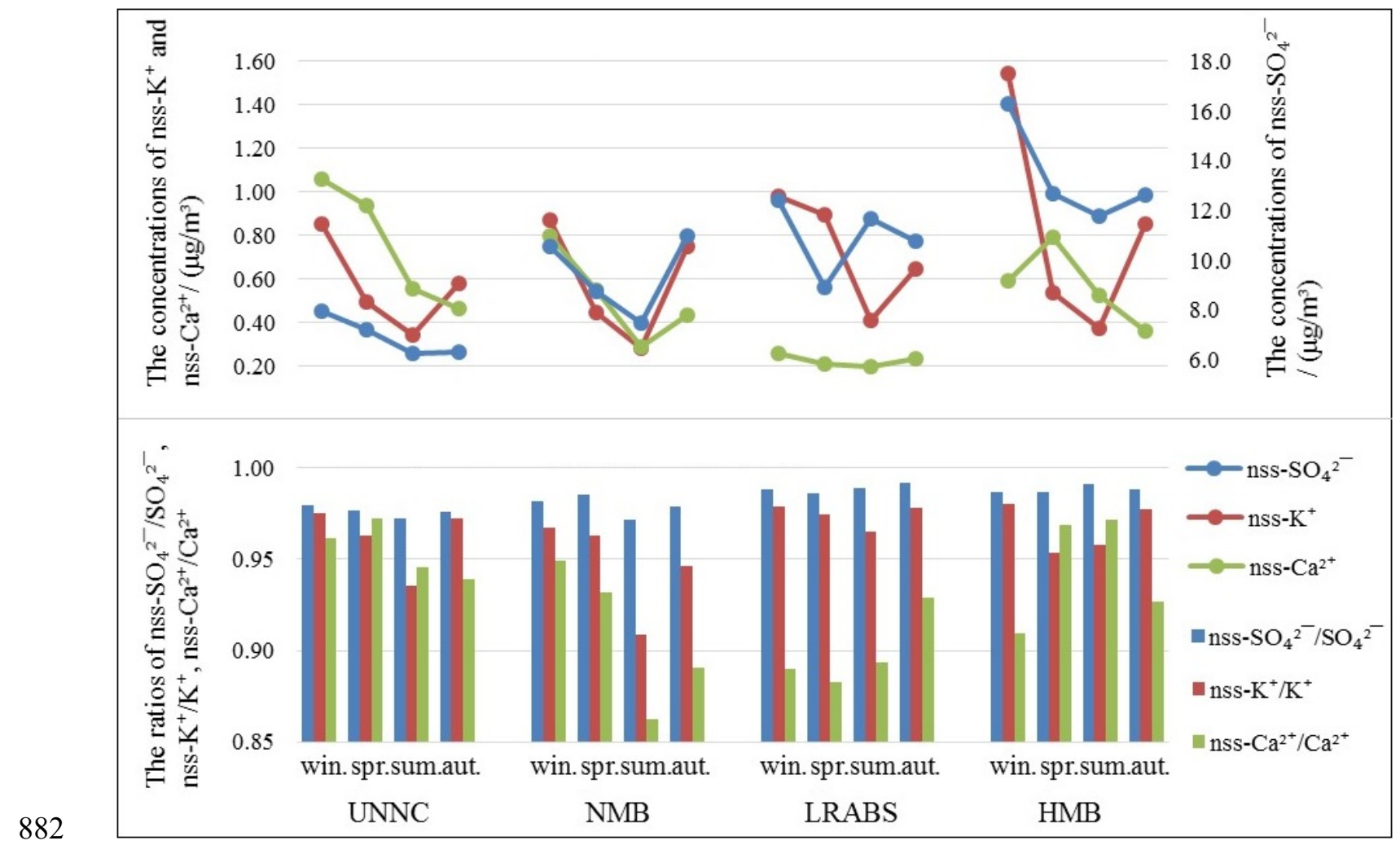

883 Fig. 5. Concentration of non-sea salts and their respective non-sea salt ionic fractions at sampling sites of NZP 


\section{List of tables}

885 Table 1 Seasonal averaged PM2.5 concentrations and meteorological data at four sampling sites 886 during the 2014-2015 sampling campaign

887 Table 2 Literature data of averaged $\mathrm{PM}_{2.5}, \mathrm{WSII}, \mathrm{SO}_{4}{ }^{2-}, \mathrm{NO}_{3}{ }^{-}$and $\mathrm{NH}_{4}{ }^{+}$concentrations in North 888 China Plain (NCP), Northwest China (NWC), Pearl River Delta (PRD) and Yangtze River Delta 889 (YRD) of China

890 Table 3 Seasonal and annual averaged WSII concentrations at four sampling sites during the $891 \quad$ 2014-2015 sampling campaign

892 Table 4 Seasonal principal component analysis results for water-soluble inorganic ions in $\mathrm{PM}_{2.5}$ 893 of NZP 
Table 1

895 Seasonal averaged $\mathrm{PM}_{2.5}$ concentrations and meteorological data at four sampling sites during the 2014-2015 896 sampling campaign

\begin{tabular}{|c|c|c|c|c|c|c|}
\hline & & $\begin{array}{l}\mathrm{PM}_{2.5} \text { concentrations } \\
\left(\mu \mathrm{g} \mathrm{m}^{-3}\right)\end{array}$ & $\begin{array}{l}\text { Wind Speed } \\
\left(\mathrm{m} \mathrm{s}^{-1}\right)\end{array}$ & $\begin{array}{l}\text { Precipitation } \\
(\mathrm{mm})\end{array}$ & $\begin{array}{l}\text { Temperature } \\
\left({ }^{\circ} \mathrm{C}\right)\end{array}$ & $\begin{array}{l}\text { Relative } \\
\text { Humidity (\%) }\end{array}$ \\
\hline \multirow{5}{*}{ UNNC } & Winter-2014 & $74.4 \pm 30.3$ & 2.4 & 0.052 & 6.5 & 64.2 \\
\hline & Spring-2015 & $44.0 \pm 17.4$ & 2.4 & 0.052 & 15.6 & 76.1 \\
\hline & Summer-2015 & $27.7 \pm 8.5$ & 2.4 & 0.110 & 26.5 & 80.1 \\
\hline & Autumn-2015 & $50.1 \pm 27.7$ & 2.2 & 0.038 & 18.0 & 76.5 \\
\hline & Annual average & $51.2 \pm 29.1$ & 2.3 & 0.063 & 16.6 & 74.2 \\
\hline \multirow{5}{*}{ NMB } & Winter-2014 & $98.1 \pm 36.4$ & 1.5 & 0.030 & 6.1 & 65.1 \\
\hline & Spring-2015 & $79.3 \pm 26.7$ & 1.7 & 0.069 & 15.9 & 71.6 \\
\hline & Summer-2015 & $33.6 \pm 11.0$ & 1.6 & 0.198 & 26.7 & 79.4 \\
\hline & Autumn-2015 & $71.2 \pm 47.5$ & 1.4 & 0.166 & 18.2 & 77.6 \\
\hline & Annual average & $70.4 \pm 40.6$ & 1.6 & 0.116 & 16.7 & 73.4 \\
\hline \multirow{5}{*}{ LRABS } & Winter-2014 & $93.7 \pm 36.4$ & 2.1 & 0.173 & 5.8 & 65.2 \\
\hline & Spring-2015 & $59.0 \pm 36.4$ & 2.0 & 0.299 & 15.5 & 72.6 \\
\hline & Summer-2015 & $42.6 \pm 18.5$ & 2.1 & 0.479 & 26.0 & 79.3 \\
\hline & Autumn-2015 & $60.7 \pm 29.7$ & 1.8 & 0.221 & 17.2 & 77.9 \\
\hline & Annual average & $66.3 \pm 36.6$ & 2.0 & 0.293 & 16.1 & 73.7 \\
\hline \multirow{5}{*}{ HMB } & Winter-2014 & $108.4 \pm 44.2$ & 2.1 & 0.014 & 6.9 & 62.1 \\
\hline & Spring-2015 & $82.6 \pm 24.5$ & 2.2 & 0.051 & 15.8 & 64.1 \\
\hline & Summer-2015 & $48.4 \pm 17.6$ & 2.1 & 0.165 & 27.7 & 72.5 \\
\hline & Autumn-2015 & $68.0 \pm 29.7$ & 1.9 & 0.052 & 19.1 & 72.1 \\
\hline & Annual average & $80.0 \pm 39.6$ & 2.1 & 0.070 & 17.4 & 67.7 \\
\hline \multirow{5}{*}{ NZP* } & Winter-2014 & $93.1 \pm 38.4$ & 2.0 & 0.067 & 6.3 & 64.1 \\
\hline & Spring-2015 & $65.1 \pm 30.9$ & 2.1 & 0.118 & 15.7 & 71.1 \\
\hline & Summer-2015 & $37.8 \pm 16.2$ & 2.0 & 0.238 & 26.7 & 77.8 \\
\hline & Autumn-2015 & $61.3 \pm 34.5$ & 1.8 & 0.119 & 18.1 & 76.0 \\
\hline & Annual average & $66.2 \pm 37.7$ & 2.0 & 0.136 & 16.7 & 72.3 \\
\hline
\end{tabular}

NZP*: Data of NZP were calculated as the average values of those in four sampling sites of NZP 
899 Literature data of averaged $\mathrm{PM}_{2.5}$, WSII, $\mathrm{SO}_{4}{ }^{2-}, \mathrm{NO}_{3}{ }^{-}$and $\mathrm{NH}_{4}{ }^{+}$concentrations in North China Plain (NCP), Northwest China (NWC), Pearl River Delta (PRD)

900 and Yangtze River Delta (YRD) of China

\begin{tabular}{|c|c|c|c|c|c|c|c|}
\hline \multirow[b]{2}{*}{ Locations } & \multirow[b]{2}{*}{ Sampling period } & \multicolumn{5}{|c|}{ Mass Concentrations $\left(\mu \mathrm{g} \mathrm{m}^{-3}\right)$} & \multirow[b]{2}{*}{ References } \\
\hline & & $\mathrm{PM}_{2.5}$ & $\begin{array}{l}\text { Total WSII (Total } \\
\text { WSII/ } \mathrm{PM}_{2.5} \text { ) }\end{array}$ & $\mathrm{SO}_{4}^{2-}$ & $\mathrm{NO}_{3}^{-}$ & $\mathrm{NH}_{4}^{+}$ & \\
\hline Handan, NCP & $2013-2014$ & $139.4 \pm 98.5$ & $63.1 \pm 35.3(45.3 \%)$ & $25.2 \pm 13.5$ & $20.6 \pm 12.2$ & $13.0 \pm 8.1$ & (Meng et al., 2016) \\
\hline Hefei, NCP & $09 / 2012-11 / 2013$ & 86.29 & $46.71(54.1 \%)$ & 15.56 & 15.14 & 7.82 & (Deng et al., 2015) \\
\hline Tianjin, NCP & $10 / 2012-08 / 2013$ & $148.9 \pm 91.1$ & $64.2(41 \%)$ & $24.2 \pm 21.8$ & $19.6 \pm 16.5$ & $8.5 \pm 5.9$ & (Zhou et al., 2016) \\
\hline Xi'an, NWC & $03 / 2012-03 / 2013$ & $169.3 \pm 101.7$ & $61.6(36.4 \%)$ & $22.2 \pm 16.8$ & $17.1 \pm 17.3$ & $9.6 \pm 8.7$ & (Niu et al., 2016) \\
\hline Weinan, NWC & $03 / 2012-03 / 2013$ & $135.5 \pm 70.0$ & $60.2(44.4 \%)$ & $24.7 \pm 16.8$ & $18.0 \pm 17.5$ & $10.0 \pm 9.1$ & (Niu et al., 2016) \\
\hline $\mathrm{Xi}$ 'an, NWC & $03 / 2006-03 / 2007$ & $194.1 \pm 78.6$ & $76.5(39.4 \%)$ & $35.6 \pm 19.5$ & $16.4 \pm 10.1$ & $11.4 \pm 6.8$ & (Zhang et al., 2011) \\
\hline Guangzhou, PRD & $04 / 2007$ & $79.2 \pm 34.2$ & $44.4(55 \%)$ & $21.6 \pm 10.7$ & $9.5 \pm 6.0$ & $7.3 \pm 3.9$ & (Tao et al., 2009) \\
\hline Zhongshan, PRD & $10 / 2012-08 / 2013$ & $60.5 \pm 46.5$ & $22.4(33 \%)$ & $9.8 \pm 6.3$ & $6.4 \pm 7.7$ & $2.8 \pm 2.8$ & (Zhou et al., 2016) \\
\hline Shanghai, YRD & $01 / 2011-12 / 2013$ & $47.0 \pm 2.0$ & $29.7(63.2 \%)$ & $10.2 \pm 0.6$ & $9.2 \pm 1.1$ & $6.0 \pm 0.7$ & (Wang et al., 2016c) \\
\hline Haining, YRD & $10 / 2012-08 / 2013$ & $109.6 \pm 59.4$ & $42.0(37 \%)$ & $16.5 \pm 9.9$ & $13.9 \pm 12.0$ & $6.1 \pm 4.3$ & (Zhou et al., 2016) \\
\hline $\begin{array}{l}\text { UNNC, Ningbo, } \\
\text { this study }\end{array}$ & $11 / 2014-11 / 2015$ & $51.2 \pm 29.1$ & $21.0 \pm 10.8(44.1 \%)$ & $7.1 \pm 3.8$ & $6.5 \pm 4.9$ & $3.9 \pm 2.0$ & This study \\
\hline $\begin{array}{l}\text { NMB, Ningbo, } \\
\text { this study }\end{array}$ & $11 / 2014-11 / 2015$ & $70.4 \pm 40.6$ & $26.7 \pm 18.8(38.6 \%)$ & $9.6 \pm 4.8$ & $7.3 \pm 8.3$ & $6.6 \pm 5.1$ & This study \\
\hline $\begin{array}{l}\text { LRABS, Lin'an, } \\
\text { this study }\end{array}$ & $11 / 2014-11 / 2015$ & $66.3 \pm 36.6$ & $29.7 \pm 18.2(44.9 \%)$ & $11.2 \pm 6.3$ & $8.7 \pm 8.5$ & $7.3 \pm 4.5$ & This study \\
\hline $\begin{array}{l}\text { HMB, Hangzhou, } \\
\text { this study }\end{array}$ & $11 / 2014-11 / 2015$ & $80.0 \pm 39.6$ & $41.3 \pm 25.5(49.2 \%)$ & $13.8 \pm 7.6$ & $14.2 \pm 11.3$ & $9.1 \pm 5.7$ & This study \\
\hline
\end{tabular}


Seasonal and annual averaged WSII concentrations at four sampling sites during the 2014-2015 sampling campaign

\begin{tabular}{|c|c|c|c|c|c|c|c|c|c|c|c|c|c|c|}
\hline \multicolumn{2}{|c|}{ Ion concentrations $\left(\mu \mathrm{g} \mathrm{m}^{-3}\right)$} & \multirow{2}{*}{$\begin{array}{l}\mathrm{Li}^{+} \\
0.0 \pm 0.0\end{array}$} & \multirow{2}{*}{$\begin{array}{l}\mathrm{Na}^{+} \\
0.5 \pm 0.1\end{array}$} & \multirow{2}{*}{$\begin{array}{l}\mathrm{NH}_{4}{ }^{+} \\
5.0 \pm 1.8\end{array}$} & \multirow{2}{*}{$\begin{array}{l}\mathrm{K}^{+} \\
0.9 \pm 0.3\end{array}$} & \multirow{2}{*}{$\begin{array}{l}\mathrm{Mg}^{2+} \\
0.1 \pm 0.0\end{array}$} & \multirow{2}{*}{$\begin{array}{l}\mathrm{Ca}^{2+} \\
1.1 \pm 1.1\end{array}$} & \multirow{2}{*}{$\begin{array}{l}\mathrm{F}^{-} \\
0.1 \pm 0.1\end{array}$} & \multirow{2}{*}{$\begin{array}{l}\mathrm{Cl}^{-} \\
2.5 \pm 1.6\end{array}$} & \multirow{2}{*}{$\begin{array}{l}\mathrm{NO}_{2}^{-} \\
0.0 \pm 0.0\end{array}$} & \multirow{2}{*}{$\begin{array}{l}\mathrm{NO}_{3}^{-} \\
10.6 \pm 5.2\end{array}$} & \multirow{2}{*}{$\begin{array}{l}\mathrm{PO}_{4}{ }^{3-} \\
0.0 \pm 0.0\end{array}$} & \multirow{2}{*}{$\begin{array}{l}\mathrm{SO}_{4}{ }^{2-} \\
8.1 \pm 4.1\end{array}$} & \multirow{2}{*}{$\begin{array}{l}\begin{array}{l}\text { Sum } \\
\text { total WSII }\end{array} \\
28.9 \pm 9.7\end{array}$} \\
\hline & Winter-2014 & & & & & & & & & & & & & \\
\hline & Spring-2015 & $0.0 \pm 0.0$ & $0.5 \pm 0.3$ & $4.0 \pm 2.0$ & $0.5 \pm 0.3$ & $0.1 \pm 0.1$ & $0.9 \pm 0.7$ & $0.1 \pm 0.1$ & $2.2 \pm 3.2$ & $0.1 \pm 0.1$ & $6.6 \pm 3.4$ & $0.0 \pm 0.0$ & $7.4 \pm 4.1$ & $22.3 \pm 11.0$ \\
\hline \multirow[t]{5}{*}{ UNNC } & Summer-2015 & $0.0 \pm 0.0$ & $0.5 \pm 0.2$ & $2.4 \pm 1.4$ & $0.4 \pm 0.1$ & $0.1 \pm 0.1$ & $0.5 \pm 0.4$ & $0.0 \pm 0.0$ & $0.4 \pm 0.7$ & $0.1 \pm 0.1$ & $2.3 \pm 1.3$ & $0.0 \pm 0.0$ & $6.4 \pm 3.4$ & $13.0 \pm 6.2$ \\
\hline & Autumn-2015 & $0.0 \pm 0.0$ & $0.4 \pm 0.1$ & $3.8 \pm 1.7$ & $0.6 \pm 0.3$ & $0.1 \pm 0.1$ & $0.5 \pm 0.4$ & $0.0 \pm 0.0$ & $0.8 \pm 0.9$ & $0.0 \pm 0.0$ & $5.4 \pm 3.9$ & $0.0 \pm 0.0$ & $6.4 \pm 3.5$ & $17.9 \pm 8.7$ \\
\hline & Annual average & $0.0 \pm 0.0$ & $0.5 \pm 0.2$ & $3.9 \pm 2.0$ & $0.6 \pm 0.3$ & $0.1 \pm 0.1$ & $0.8 \pm 0.8$ & $0.0 \pm 0.1$ & $1.5 \pm 2.0$ & $0.0 \pm 0.1$ & $6.5 \pm 4.9$ & $0.0 \pm 0.0$ & $7.1 \pm 3.8$ & $21.0 \pm 10.8$ \\
\hline & Winter-2014 & $0.0 \pm 0.0$ & $0.7 \pm 0.3$ & $9.4 \pm 4.4$ & $0.9 \pm 0.4$ & $0.1 \pm 0.0$ & $0.8 \pm 0.8$ & $0.0 \pm 0.0$ & $3.5 \pm 2.3$ & $0.1 \pm 0.2$ & $10.3 \pm 7.6$ & $0.0 \pm 0.0$ & $10.7 \pm 4.0$ & $36.4 \pm 16.3$ \\
\hline & Spring-2015 & $0.0 \pm 0.0$ & $0.4 \pm 0.1$ & $5.9 \pm 3.8$ & $0.5 \pm 0.2$ & $0.1 \pm 0.0$ & $0.5 \pm 0.4$ & $0.1 \pm 0.4$ & $0.9 \pm 0.8$ & $0.7 \pm 0.7$ & $5.5 \pm 4.0$ & $0.1 \pm 0.4$ & $8.8 \pm 4.6$ & $23.4 \pm 12.4$ \\
\hline \multirow[t]{5}{*}{ NMB } & Summer-2015 & $0.0 \pm 0.0$ & $0.7 \pm 0.5$ & $3.2 \pm 1.8$ & $0.3 \pm 0.3$ & $0.1 \pm 0.0$ & $0.2 \pm 0.3$ & $0.2 \pm 0.5$ & $0.3 \pm 0.3$ & $0.2 \pm 0.3$ & $1.7 \pm 1.4$ & $0.0 \pm 0.0$ & $7.6 \pm 3.1$ & $14.5 \pm 5.7$ \\
\hline & Autumn-2015 & $0.0 \pm 0.0$ & $0.6 \pm 0.2$ & $7.5 \pm 7.2$ & $0.8 \pm 0.7$ & $0.0 \pm 0.0$ & $0.2 \pm 0.4$ & $0.0 \pm 0.0$ & $1.1 \pm 0.9$ & $0.3 \pm 0.3$ & $10.3 \pm 12.4$ & $0.0 \pm 0.0$ & $11.2 \pm 6.7$ & $32.0 \pm 27.0$ \\
\hline & Annual average & $0.0 \pm 0.0$ & $0.6 \pm 0.4$ & $6.6 \pm 5.1$ & $0.6 \pm 0.5$ & $0.1 \pm 0.0$ & $0.4 \pm 0.5$ & $0.1 \pm 0.3$ & $1.5 \pm 1.8$ & $0.3 \pm 0.4$ & $7.0 \pm 8.3$ & $0.0 \pm 0.2$ & $9.6 \pm 4.8$ & $26.7 \pm 18.8$ \\
\hline & Winter-2014 & $0.1 \pm 0.1$ & $0.5 \pm 0.2$ & $10.2 \pm 5.6$ & $1.0 \pm 0.4$ & $0.2 \pm 0.2$ & $0.3 \pm 0.2$ & $0.1 \pm 0.1$ & $1.3 \pm 1.1$ & $0.1 \pm 0.1$ & $15.2 \pm 8.7$ & $0.2 \pm 0.1$ & $12.5 \pm 7.1$ & $41.6 \pm 20.9$ \\
\hline & Spring-2015 & $0.0 \pm 0.1$ & $0.4 \pm 0.2$ & $7.5 \pm 3.9$ & $0.9 \pm 1.5$ & $0.1 \pm 0.1$ & $0.2 \pm 0.1$ & $0.0 \pm 0.1$ & $0.5 \pm 0.6$ & $0.2 \pm 0.1$ & $8.5 \pm 9.3$ & $0.0 \pm 0.1$ & $9.0 \pm 4.8$ & $27.4 \pm 17.4$ \\
\hline \multirow[t]{5}{*}{ LRABS } & Summer-2015 & $0.0 \pm 0.0$ & $0.3 \pm 0.1$ & $4.9 \pm 3.2$ & $0.4 \pm 0.2$ & $0.0 \pm 0.0$ & $0.2 \pm 0.1$ & $0.0 \pm 0.0$ & $0.2 \pm 0.1$ & $0.2 \pm 0.2$ & $2.4 \pm 2.0$ & $0.1 \pm 0.2$ & $11.8 \pm 7.4$ & $20.6 \pm 12.5$ \\
\hline & Autumn-2015 & $0.0 \pm 0.1$ & $0.3 \pm 0.1$ & $5.9 \pm 2.5$ & $0.7 \pm 0.3$ & $0.1 \pm 0.1$ & $0.2 \pm 0.2$ & $0.0 \pm 0.0$ & $0.3 \pm 0.3$ & $0.1 \pm 0.1$ & $6.7 \pm 5.3$ & $0.0 \pm 0.0$ & $10.9 \pm 4.7$ & $25.1 \pm 11.6$ \\
\hline & Annual average & $0.0 \pm 0.1$ & $0.4 \pm 0.2$ & $7.3 \pm 4.5$ & $0.8 \pm 0.7$ & $0.1 \pm 0.1$ & $0.2 \pm 0.2$ & $0.0 \pm 0.1$ & $0.6 \pm 0.8$ & $0.1 \pm 0.1$ & $8.7 \pm 8.5$ & $0.1 \pm 0.2$ & $11.2 \pm 6.3$ & $29.6 \pm 18.2$ \\
\hline & Winter-2014 & $0.0 \pm 0.0$ & $0.7 \pm 0.3$ & $13.5 \pm 6.7$ & $1.6 \pm 0.7$ & $0.1 \pm 0.0$ & $0.6 \pm 0.5$ & $0.2 \pm 0.0$ & $3.4 \pm 2.3$ & $0.0 \pm 0.1$ & $21.9 \pm 12.6$ & $0.1 \pm 0.1$ & $16.5 \pm 9.6$ & $58.5 \pm 29.7$ \\
\hline & Spring-2015 & $0.0 \pm 0.0$ & $0.5 \pm 0.2$ & $7.7 \pm 3.2$ & $0.6 \pm 0.3$ & $0.5 \pm 0.3$ & $0.8 \pm 0.4$ & $0.0 \pm 0.1$ & $1.0 \pm 0.8$ & $0.2 \pm 0.3$ & $13.3 \pm 8.1$ & $0.0 \pm 0.1$ & $12.8 \pm 6.1$ & $37.6 \pm 16.8$ \\
\hline \multirow[t]{3}{*}{ HMB } & Summer-2015 & $0.0 \pm 0.0$ & $0.4 \pm 0.3$ & $5.5 \pm 3.2$ & $0.4 \pm 0.3$ & $0.2 \pm 0.2$ & $0.5 \pm 0.5$ & $0.0 \pm 0.0$ & $0.4 \pm 0.5$ & $0.1 \pm 0.1$ & $5.7 \pm 5.8$ & $0.0 \pm 0.1$ & $11.9 \pm 6.2$ & $25.2 \pm 15.7$ \\
\hline & Autumn-2015 & $0.0 \pm 0.0$ & $0.4 \pm 0.3$ & $7.3 \pm 3.3$ & $0.9 \pm 0.4$ & $0.1 \pm 0.0$ & $0.4 \pm 0.2$ & $0.0 \pm 0.0$ & $0.9 \pm 0.6$ & $0.1 \pm 0.1$ & $12.3 \pm 8.9$ & $0.2 \pm 0.3$ & $12.7 \pm 6.0$ & $35.2 \pm 18.0$ \\
\hline & Annual average & $0.0 \pm 0.0$ & $0.5 \pm 0.3$ & $9.1 \pm 5.7$ & $0.9 \pm 0.7$ & $0.2 \pm 0.2$ & $0.6 \pm 0.4$ & $0.1 \pm 0.1$ & $1.7 \pm 1.9$ & $0.1 \pm 0.2$ & $14.2 \pm 11.3$ & $0.1 \pm 0.2$ & $13.8 \pm 7.6$ & $41.3 \pm 25.5$ \\
\hline
\end{tabular}


904 Seasonal principal component analysis results for water-soluble inorganic ions in $\mathrm{PM}_{2.5}$ of northern Zhejiang 905 Province

\begin{tabular}{|c|c|c|c|c|c|c|c|c|c|c|}
\hline \multirow{3}{*}{ Season } & \multicolumn{3}{|c|}{ 2014-Winter } & \multicolumn{2}{|c|}{ 2015-Spring } & \multicolumn{2}{|c|}{ 2015-Summer } & \multicolumn{3}{|c|}{ 2015-Autumn } \\
\hline & \multicolumn{3}{|c|}{ Component } & \multicolumn{2}{|c|}{ Component } & \multicolumn{2}{|c|}{ Component } & \multicolumn{3}{|c|}{ Component } \\
\hline & 1 & 2 & 3 & 1 & 2 & 1 & 2 & 1 & 2 & 3 \\
\hline $\mathrm{Na}^{+}$ & 0.555 & 0.582 & & 0.687 & 0.337 & 0.342 & 0.642 & 0.413 & 0.571 & 0.490 \\
\hline $\mathrm{NH}_{4}^{+}$ & 0.931 & & & 0.806 & - & 0.835 & - & 0.957 & & \\
\hline $\mathrm{K}^{+}$ & 0.868 & & & 0.675 & & 0.820 & & 0.942 & & \\
\hline $\mathrm{Mg}^{2+}$ & & 0.377 & 0.744 & 0.438 & 0.505 & & 0.554 & & 0.695 & -0.348 \\
\hline $\mathrm{Ca}^{2+}$ & & 0.730 & & & 0.815 & 0.484 & 0.673 & 0.311 & 0.505 & -0.623 \\
\hline $\mathrm{Cl}^{-}$ & 0.558 & 0.507 & & 0.465 & 0.534 & 0.564 & 0.359 & 0.442 & 0.538 & 0.450 \\
\hline $\mathrm{NO}_{2}^{-}$ & & - & 0.725 & & & & & & & $\mathbf{0 . 5 3 3}$ \\
\hline $\mathrm{NO}_{3}^{-}$ & 0.891 & & & 0.910 & & 0.846 & & 0.949 & & \\
\hline $\mathrm{SO}_{4}{ }^{2-}$ & 0.882 & & & 0.729 & & 0.840 & - & 0.848 & & \\
\hline Initial eigenvalue & 3.856 & 1.539 & 1.168 & 3.383 & 1.670 & 3.473 & 1.799 & 4.002 & 1.456 & 1.295 \\
\hline$\%$ of Variance & 42.84 & 17.09 & 12.98 & 37.59 & 18.55 & 38.58 & 19.98 & 44.46 & 16.17 & 14.38 \\
\hline explained & 8 & 8 & 3 & 0 & 3 & 8 & 4 & 3 & 5 & 7 \\
\hline$\%$ of Cumulative & 42.84 & 59.94 & 72.92 & 37.59 & 56.14 & 38.58 & 58.57 & 44.46 & 60.63 & 75.02 \\
\hline variance & 8 & 6 & 9 & 0 & 3 & 8 & 1 & 3 & 7 & 4 \\
\hline
\end{tabular}

906 Blanks in table are value $<0.3$ 